Portland State University

PDXScholar

1981

\title{
A history of the Portland waterfront between southwest Clay and Washington streets, its land use and legal problems
}

Jeffrey G. Carter

Portland State University

Follow this and additional works at: https://pdxscholar.library.pdx.edu/open_access_etds

Part of the History Commons, Land Use Law Commons, and the Urban Studies Commons Let us know how access to this document benefits you.

Recommended Citation

Carter, Jeffrey G., "A history of the Portland waterfront between southwest Clay and Washington streets, its land use and legal problems" (1981). Dissertations and Theses. Paper 3236.

https://doi.org/10.15760/etd.3230

This Thesis is brought to you for free and open access. It has been accepted for inclusion in Dissertations and Theses by an authorized administrator of PDXScholar. Please contact us if we can make this document more accessible: pdxscholar@pdx.edu. 
AN ABSTRACT OF THE THESIS OF Jeffrey G. Carter for the Master of Arts in History presented October 21, 1981

Title: A History of the Portland Waterfront Between Southwest Clay and washington Streets, Its Land Use and Legal Problems

APPROVED BY MEMBERS OF THE THESIS COMMITTEE
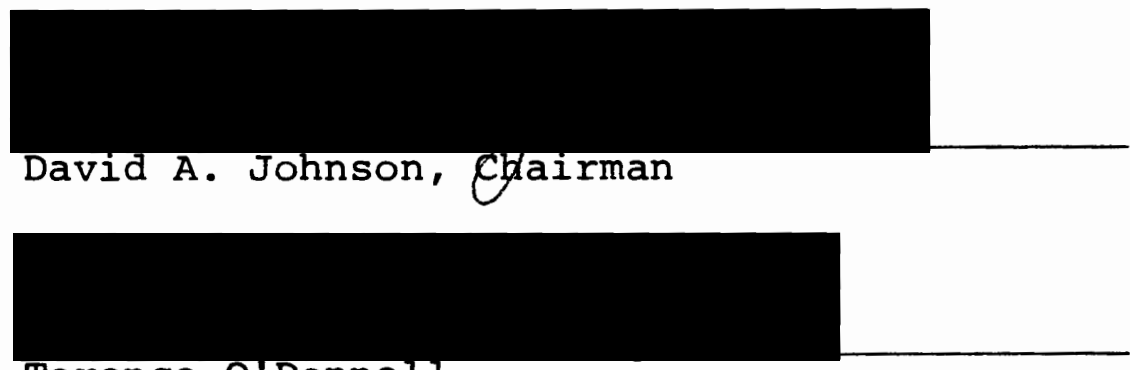

Terence O'Donnell

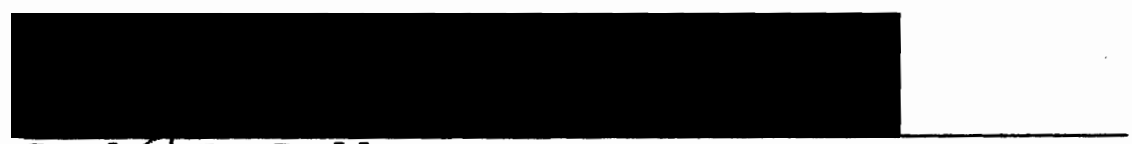

Gord $\phi$ B. Dodds

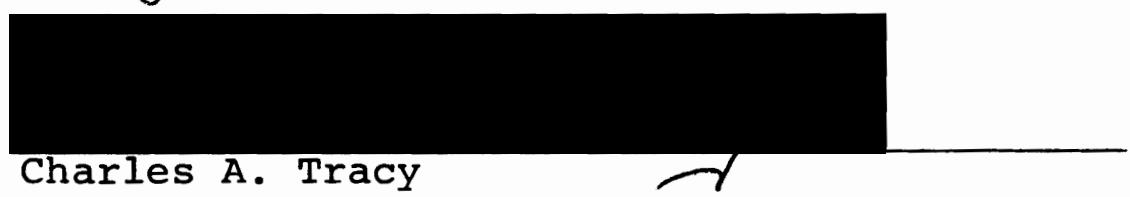

Between 1845 and 1980 the Portland waterfront between southwest Washington and Clay Streets, east of Front Street, metamorphosed from wilderness to trade center, to highway, to inner-city vacant lot. No place in Portland has more graphically illustrated the rapidly changing forces of the modern age in which the city has grown. 
For much of its history this stretch of waterfront was mired in law suits. The struggles centered on public versus private ownership. Originally dedicated as public property, but left unimproved by the city, the waterfront was usurped by private investors. Eventually, private owners allowed their property to decay prompting the public to encourage improvements. The legal battles even became reversed as private investors sought to force the sale of the waterfront to the city.

Through all the confusion of legal battles this stretch of waterfront played a central role in the development and identity of Portland. It has finally become, undisputed public territory. The tension and greed of private investment have been replaced by the lack of municipal funds for esthetic improvement and have left this stretch of land, a potentially fine and important urban park, a vacant lot. 


\title{
A HISTORY OF THE PORTLAND WATERFRONT
} BETWEEN SOUTHWEST CLAY AND WASHINGTON STREETS, ITS LAND USE AND LEGAL PROBLEMS

\author{
by \\ JEFFREY GERALD CARTER
}

\begin{abstract}
A thesis submitted in partial fulfillment of the requirements for the degree of
\end{abstract}
MASTER OF ARTS
in
HISTORY

Portland State University

1983 
TO THE OFFICE OF GRADUATE STUDIES AND RESEARCH:

The members of the Committee approve the thesis of Jeffrey G. Carter presented October 21, 1981 .

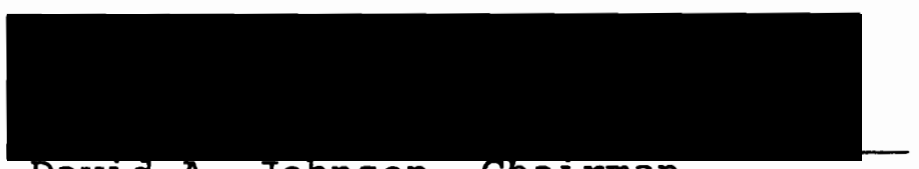

David A. Johnson, Ghairman

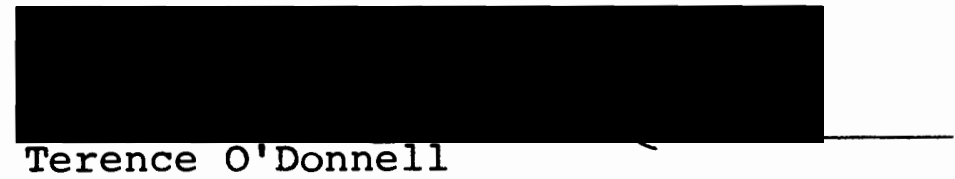

Gordof B. Dodds

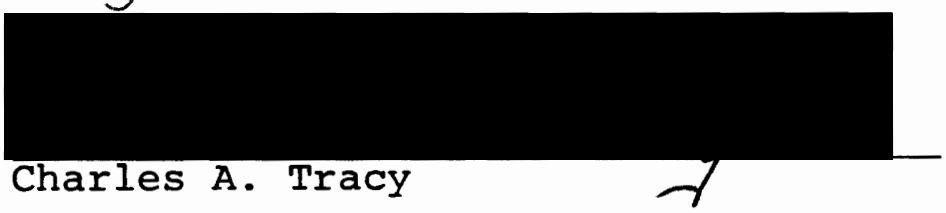

APPROVED :

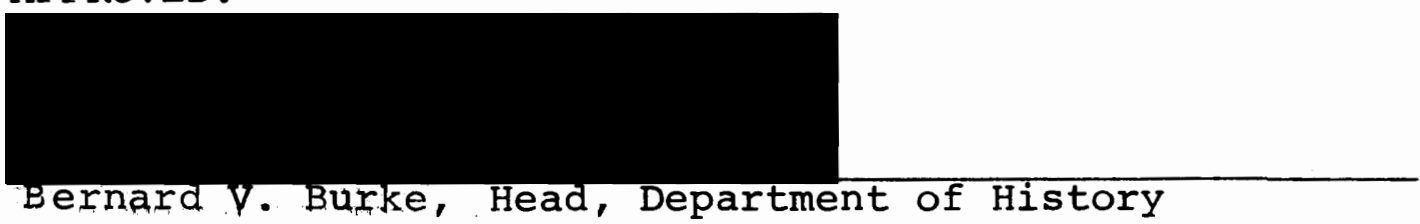

Bernard v. Burke, Head, Department of History

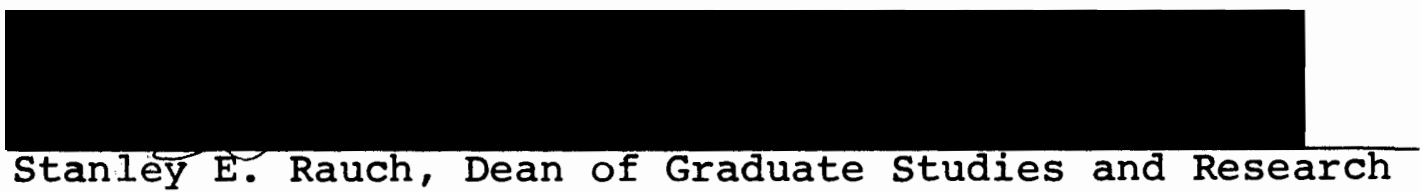




\section{PREFACE}

The history of the southwest Portland waterfront between Washington and Clay Streets, east of Front, reveals much of the character of the city and reflects the major economic and political developments that influenced its growth. Almost half of the area's 135 year history has involved bitter legal battles that consistently pitted private and public interests against one another. The earliest battles illustrate the anarchy seldom associated with the opening of the American frontier; the weak central authority and the confusion of land claims and rights. The next major legal dispute involved the struggle of rural, farming interests against urban, commercial interests and the activities of transportation monopolies. The interaction of these groups on the waterfront gives a good example of the reasons behind the populist and progressive movements of the late nineteenth and early twentieth centuries.

The history of the waterfront in the twentieth century is the story of the return of the property to governmental control and the struggle to develop it for community purposes. Throughout the area's history is the painful confrontation between private and public interests. It 
proves that the tension between the same forces that we are experiencing in the 1980 s is well founded in history. 
TABLE OF CONTENTS

PAGE

PREFACE

iii

CHAPTER

I THE FOUNDING OF PORTLAND AND THE PUBLIC

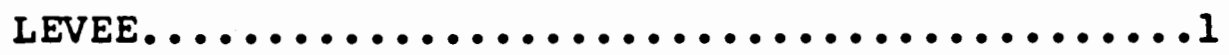

II INTRODUCTION.........................42

COFFIN'S PUBLIC LEVEE AND THE RAILROAD........43

III INTRODUCTION........................ COFFIN'S LEVEE IN THE TWENTIETH CENTURY......77 THE ORIGINAL PUBLIC LEVEE IN THE TWENTIETH CENTURY................................ 84

IV CONCLUSION........................94

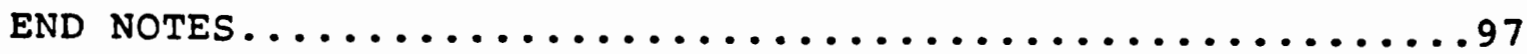

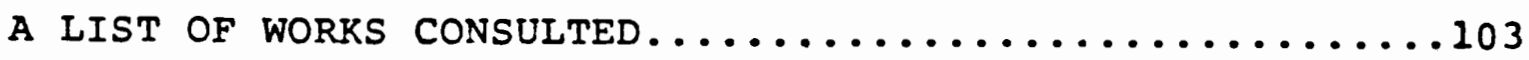




\section{CHAPTER I}

THE FOUNDING OF PORTLAND

AND THE PUBLIC LEVEE

In the 1840 's, large estates were being broken up in the American Northeast, most notably in the anti-rent wars of New York state. The rent war was a revolt against the feudal and communal landlord-tenant farmer land use system, remaining from the colonial era. The revolt was in favor of individual ownership and against central authority over land use.

At this same time, Americans had just begun to acquire square mile tracts of land in the Northwest. In 1843, William Overton and Asa Lovejoy acquired one of those square miles on the west bank of the Willamette River. They claimed what was to become the city of portland.

In a gesture recalling medieval concepts of communal land use, the river front of the tiny village was to be dedicated as a public levee, open and free to all. Such feudal concepts were being rejected in the Northeast in the rent war. The idea was a generous one, but the modern concepts that capitalism and individual land rights are paramount to those of the public were to make a battlefield of Portland's Front street. 
In 1843, when the town site was originally claimed, the oregon Territory was claimed by both Great Britain and the United States. Land ownership was disputed on an international level, but the pressure of the American westward movement led to the organization of a provisional and unauthorized government. This government, claiming to hold the land of Oregon in the name of the United States, issued individual titles to property for the nominal filing fee of twenty-five cents. ${ }^{1}$

The Overton-Lovejoy claim, though the future site of a major metropolis, was no different from many other early land claims. It changed hands. Despite the difficulties of travel in frontier America, early pioneers were often footloose. Overton spent the winter of 1843-44 on his new claim, but in the spring he bartered his half to Francis Pettygrove for fifty dollars worth of provisions and disappeared from the vicinity.

The new partnership of Lovejoy and Pettygrove was centered in Oregon City, the major American settlement in the region at that time. The partners hired a man to build a cabin near what is now the foot of Washington and Front streets. It was the first building built on the town claim. By 1845, Lovejoy and Pettygrove had perceived their claim's potential as the farthest inland point of deep water from the mouth of the Columbia River. The economic advantages of avoiding transshipping goods from the ocean-going ships at 
British Fort Vancouver for shallow draft transportation to Oregon City, were not lost upon the two town proprietors.

Pettygrove's New England connections enabled him to be one of the major suppliers of finished products to the burgeoning, though rough oregon frontier. He invested in the construction of a warehouse and wharf at the Portland site. He and Lovejoy hired a surveyor to produce a town plat, which consisted of the eighteen blocks between southwest Jefferson and Washington streets and Front and Second Avenues. By 1846, ships were making infrequent calls at the tiny port; the waterfront was born.

Lovejoy sold his half of the claim to a seafarer, Benjamin Stark, in 1846. In that year, the British-American boundary dispute was settled, though the makeshift Provisional Government was not organized as an offical territory of the United States until 1848, and Congress did not create an official mechanism for the transfer of land titles to individuals until 1850 .

In september of 1848 , Pettygrove sold his claim to Daniel H. Lownsdale, who also held the 640-acre claim immediately to the west. Less than a year later, Lownsdale sold an undivided half of the claim to stephen Coffin. A few months later, these two men accepted william $w$. Chapman as a third partner. Lownsdale also paid a visit to Benjamin Stark, who had settled in San Francisco, but who was still half owner of the town claim. Lownsdale, to simplify the 
transfer of town lots to settlers, needed to define which half belonged to stark and which to the three partners. For whatever reason, Stark wound up with the 48 acres north of Stark street, most of which had already been sold. Though Stark was given the money already received from the sale of the lots in that section, Lownsdale, Chapman and Coffin retained 600 acres of increasingly valuable, mostly undeveloped town site. This was the earliest example of Lownsdale's efforts to retain control of the town site property.

By 1850 Oregon had found a market for her lumber and food products in California. The gold rush opened the door to economic development in oregon. Water transportation was the fastest, cheapest means of moving produce, and Portland, with her deep water port in the heart of a naturally bountiful and increasingly settled land, became the shipping center of the Northwest. Money was to be made from the river and the waterfront was the place to be for anyone who was seeking his fortune in Portland.

Early maps of the town site, drawn up between Lovejoy, Pettygrove and stark, left the waterfront unplatted for private development and access to the river open and free to all. This altruistic gesture was out of step with the forces that developed Portland and was to become an endless source of litigation for the young town.

In 1850, Lownsdale, Chapman and Coffin commissioned a 
new plat of Portland. This became known as the Brady Map, after the cartographer who made it. On this map, the land along the river bank was divided into blocks, thus indicating that the only legal public access to the river was by those streets which had openings on the river. The town proprietors proceeded to sell river-front lots to settlers and to consolidate their holdings by selling to one another. Until the summer of 1850 , these three major land holders had participated in a joint partnership, but during that summer they divided the claim among them, each to be responsible for the sale of his own lots and blocks. Daniel Lownsdale retained the waterfront between washington and Jefferson streets. 3

As a result of the sale of waterfront land, the first law suit involving the Public Levee was filed on July 29, 1850, by Josiah Parrish, whose lot on the west side of Front Street was blocked from river access by construction of a building. Parrish claimed access to the river as a property right; he sued both the builders and Daniel Lownsdale for having sold the land to private developers.

Ever since Pettygrove had built his first warehouse and wharf on the waterfront, the area north of Washington Street had been under development. That area had not been included in the town's original plat and thus, was not generally considered to be a part of the Public Levee. Commerce was also being drawn north by the construction of 
wharves on the land claim of John H. Couch, north of Ankeny Street. Development of the north river bank challenged Lownsdale to develop his open river bank in order to increase the value of his lots and blocks as commercially attractive investments.

Lownsdale's developments did not set well with J.L. Parrish, and other lot holders on the west side of Front Street, for these developments impaired what they considered to be their commercial advantage of open river access. Parrish was called upon by a number of gentlemen, Lownsdale among them, and a compromise was reached. If Parrish would drop his suit, Lownsdale would dedicate the rest of the waterfront land between Washington and Jefferson streets to the public. At the time of this meeting Mr. Parrish was ill; upon his recovery he repudiated the compromise, claiming he had been taken advantage of on his sick bed. ${ }^{4}$

Judge Orville Pratt, of the Washington County Circuit Court, granted an injunction against construction on the Levee, declaring the plat commissioned by Pettygrove to be the true map of Portland and defining front street as extending to the river from Jefferson street on the south to about Burnside on the north. 5

On January 23, 1851, the territorial legislature passed "A Bill to incorporate the city of Portland." It was the first charter of the young town. The charter stated that the Common (City) Council would have the right to "regulate 
Front street on the river from the old wharf to the ferry landing" and the right to provide for removal of all obstructions in "the streets, lanes, or alleys or on the public levees thereof." 6

The seventh ordinance of the first Common Council, passed May 17, 1851 stated,". . that hereafter no person or persons shall erect or cause any buildings, or in any other way obstruct the Public Levees." Offenders were to be fined fifty dollars and have the obstruction removed at their own expense. 7 The public was laying claim to the riverfront, or at least to the portion of it between Washington and Jefferson Streets.

Daniel Lownsdale had other ideas. The Weekly eregonian, during the spring of 1851 , carried a notice in which the town proprietor forbade any trespass upon his lands bounded on the west by Front street (specifically defined as being sixty feet wide), consisting of the blocks between Washington on the north and Main on the south.

All persons [were]. - forbidden to dig down any of the banks, erect any buildings on the same, or placing any [sic.] on them any wood, lumber, or any other material whatever.

Public and private parties were lining up on the battlefield of Front street.

Every spring, the voters of Portland elected new officers. Those elected in the spring of 1852 made a great blunder regarding the city's claim to the Public Levee. On April 18, 1852 the common council voted to accept the map 
commissioned by the three proprietors and drawn by John Brady in 1850 as the official map of the city. This was the map which laid the waterfront off into blocks. From this date onward, it would be argued that by this act the city government recognized that front street was sixty feet wide, as was any other street, and that the land east of it was laid off in blocks, indicating that the council accepted the waterfront as private property.

At the same time, however, the council also formed a special committee, consisting of A.P. Dennison, Josiah Failing and Abell Tripp. This committee's special task was to obtain from the city proprietors a "bond or deed of all Public streets and deed of trust for all land donated to Benevolent societies, Public Schools, Squares, etc." The make-up of the committee is of interest in two respects. Dennison was a party to the original Levee suit, brought against him and others by J.L. Parrish, and Mr. Tripp immediately resigned his commission. ${ }^{9}$

Though the committee had a strong element of pro-private waterfront, a resolution was also passed recognizing the Public Levee. The council resolved to maintain the public's claim to the land granted in the compromise offered, though subsequently rejected, in the case of Parrish vs. Lownsdale, and "to act accordingly until otherwise instructed by the decision of the case now pending in court in actation thereto." 10 Parrish was, at the time, 
seeking to make permanent the injunction against construction on the Levee which had been granted by Judge Pratt against Councilman Dennison and others.

The indications are that the council may have been more in favor of private than of public property yet, by the creation of the special committee and the Levee resolution, had thought to protect the public's interest in land titles. By adopting the Brady map the council appears to have been trying to get the most complete map of the city without expending funds for a new survey. The council was attempting to go "first class on a steerage ticket." This trait has been held to be one of Portland's most characteristic means of doing business. ${ }^{11}$ In any case, the council of 1852 was sending mixed signals.

It is not very surprising that the special committee for obtaining leases to public property did not report until the week before new elections. The report offered on March 14, 1853 stated that proprietors Chapman and Coffin were willing to give deeds to all streets and "public donations," if Lownsdale would do the same. However, Lownsdale declined to make such an offer until the question of who owned the town site was settled. No deeds to public property were obtained. Another indication of the dispostion of the town proprietors toward donating land for the public good arose at the same council meeting. A special committee, previously charged with the responsibility of securing a 
proper burial site from the town proprietors, reported their findings; what had been offered was "low and marshy" and totally inappropriate to the purpose. Both committees begged relief of their duties, which was granted with no further provisions. ${ }^{12}$

The settlement of the ownership of the Portland town site claim was a new and frustrating development for the town and further complicated the Levee issue. The Donation Land Law had been passed by the United States Congress in September, 1850. Since that time it had become apparent that the proprietors could not file jointly for the land claim. On March 10, 1853, Chapman, Coffin and Lownsdale entered into a bonded agreement to seek final title to the land claim, each to his agreed-upon tract of land. Upon receiving title they would pass deeds to those to whom they had sold lots.

Lownsdale and Chapman made their notifications to the Land Office in Oregon City on March 11. Coffin, whose claim had not been fully surveyed, had to wait until August. However, less than a month after Lownsdale had filed his partial claim, he filed a second claim. This time to the entire donation tract. ${ }^{13}$

Lownsdale's attorney, A.E. Wait, argued that the three proprietors had, at one time, been partners, each possessing equal rights, except that Lownsdale, as the one in whose name the original claim was held, "was the admitted, sole, 
rightful claim holder." However, with the public sale of land and the division of the claim between them in 1850 , "their joint interest became severed"; after this time each had sold land separately. Therefore, "the joint interest of the parties in the claim, having ceased, and Lownsdale remaining sole claim holder, all reasons for joint actions towards procuring a patent from the united States also ceased." 14 Chapman and Coffin were threatened with becoming no more than any other lot or block holder and threatenec with loss of the land to which they had not specifically obtained deeds.

Lownsdale also argued that the bond he had entered into with Coffin and Chapman was proof of his ownership. The agreement stated,

Being the same tract which the said Lownsdale purchased from Francis Pettygrove. . - whereas the said Lownsdale, Coffin and Chapman have sold lots in said City of Portland to each other and to third persons obligating themselves to make to the grantees a deed of general warranty. 15

The only mention of ownership was that of Lownsdale; the other two were cast in the light of grantees. Lownsdale even argued that half of the original claim legally belonged to his wife.

Lownsdale lost. On June 24, the Surveyor General of Oregon granted him only that portion of land claimed in his first, limited notification. Perhaps if Lownsdale had been granted the entire claim, his greed would have been assuaged, and he might have granted the city the Public 
Levee, but this was not the case.

Lownsdale was a southern Democrat. There was no love lost between him and the Whig editor of the reekly oregonian, Thomas Dryer. On November 5, 1853, an article appeared which praised Coffin and Chapman for their desires to provide warrantee deeds to all those to whom they were due. However,

On the other hand, D.H. Lownsdale refuses to abide by the [Surveyor General's] decision, notwithstanding his covenant. . We are credibly informed that letters have been written, by parties interested with Lownsdale to President Pierce, setting forth this matter in a political light; in the hope they may secure a party bias in the review of the case pending before the commissioner of the general land office. In this they are doomed to disappointment. They are mistaken in supposing the president or the commissioner to be as corrupt as themselves.

Dryer went on to disparage Lownsdale and his cohorts as "... as anomalies of the human race, bent on doing all the injury they can to themselves and others." 16

The common council of 1854 was elected under a new charter, which no longer mentioned front street specifically as public property, nor did the charter have the words "Public Levee" included in it. The territorial legislature had extricated itself from that particular mire through the expedient of vagueness. The new charter gave the council the duty to "erect, repair and regulate public wharves and docks, to regulate the erection and repairs of private wharves and $f i x$ the rates of wharfage thereof." 17

William S. Ladd, future Portland tycoon, was elected 
mayor in the spring of 1854 , but requested leave of his duties. A.P. Dennison was appointed acting mayor for the term. Dennison had been a defendant in the original suit brought by J.L. Parrish against developers on the open Levee; he was also a member of the committee which had failed to obtain deeds to public property from Lownsdale. At least two councilmen elected that year, A.P. Starr and Thomas Carter, were private waterfront owners who were later involved in law suits concerning the Levee.

Though Portland had a new charter and, as a burgeoning trade center, needed new laws, no new ordinances had been passed a month after the city elections. Dryer of the Weekly Oregonian was livid. "As we predicted," he wrote, "the present city council have among its members restless, domineering, mulish and spleeny men," controlled by "narrow-minded, dictatorial speculators." 18

At this same time, Judges George H. Williams, Cyrus Olney and Matthew Deady of the Territorial Supreme Court had made their decision regarding the appeal of Pratt's injunction against Levee construction. Front street was defined by the court as extending in the south from Jefferson Street to the south side of John H. Couch's land claim, and, most importantly, had as its eastern boundary the Willamette River. The decree perpetually enjoined the erection of buildings on the street and called Lownsdale, Coffin and Chapman to pay court costs. This decision was 
appealed, even though existing tenantable buildings were not required to be removed. The city was required to petition the court for permission to remove those buildings when it should become necessary.19 Matthew Deady dissented from this decision.

On May 6, 1854, editor Dryer of the Weekly Oregenian predicted, "If the members of the present City Council shall undertake to repudiate the decisions of the court. . nothing but confusion, discords and dissensions can be expected."

On top of the unceasing litigation over the ownership of the Levee and the townsite, a new problem was added on June 10, 1854. The year before, Lownsdale had appealed his defeated attempt to wrest control of the townsite from his partners. The appeal backfired when the decision of the Federal Land Office was made. The Donation Land Law was held not to apply; instead an 1844 law enabling town governments to make claims of United States lands was held to be valid. The Donation Law, it was argued, had been designed for agricultural lands, while the 1844 Townsite Law had been designed to protect town settlers from speculators.

The decision stated that,

It is true that the golden dreams of those who have attempted thus to claim these lands may be dissipated but the greatest good of the greatest number will be legaliy and equitably secured, and the spirit and the letter of the laws carried out. 20

Needless to say, the powers of Portland were not going to 
accept this decision without a fight. Governor Joseph Lane, a Southern Democrat, as was Lownsdale, immediately appealed the decision.

It may have been the only thing T.J. Dryer and Lane ever agreed upon. Dryer decried the decision as an injustice to the pioneers, and wrote, "The donation of land which allured the great majority of settlers in oregon to seek a home on the shores of the Pacific, will come to be regarded as a curse rather than a boon. ${ }^{21}$

Despite the continued insecurity of land titles, Portland's population grew and its traffic increased. By 1854, it was a town rapidly outstripping nearby rivals as the regional center for commerce.

Portland's government had to respond to these economic developments. In July 1854, the council passed the first resolution to grade and survey front street. According to the city charter, all improvements made on a street were to be financed two-thirds by the adjacent property owners and one-third by the city. Everyone owning property on either side of Front Street was assessed his share of the cost of grading. This contradicted the recent supreme court decision which declared the Levee to be public property. In August, the council was inundated with petitions to lower the valuation of poperties on both sides of the street. Among the petitioners were Councilman starr and Mayor Dennison. Starr was granted his request, as were most other 
petitioners, but the mayor and another man involved with him, Thomas stephens, had their requests rejected. They had been parties to the original Levee suit. Perhaps the council was trying to make them a little uncomfortable in return for the discomfort they had caused the city.

On August 14, 1854, the council made its biggest mistake since adopting the Brady map. Councilman Fitch, undoubtedly tired of the clamor for reevaluation of land by people who, by court decision, did not own it, moved that the council resolve to deduct assessments of lots on the Levee from the tax rolls. It is interesting to consider what reaction his fellow councilmen may have had. Perhaps they sneered as the resolution was defeated four to one, with four councilmen absent.

Councilman A.P. Starr was not in the chamber that day. He may have been celebrating his recent victory. A.M. and L.M. Starr, later founders of the First National Bank of Oregon, had, earlier in 1854, begun construction on a Levee lot, and subsequently been taken to court. This suit was a test to see whether the decree of the Territorial supreme Court, which placed an injunction on Levee construction and provided for the removal of structures from the Levee by petition to the court, could be enforced. A circuit court decision held that the supreme Court decree could not be enforced because it pertained only to buildings on the Levee at the time of the decree. The circuit court held that 
the starrs, not having been parties to the original suit, were not bound by the supreme court decision. In reaction to the starr decision, the committee on landings and wharves recommended that the city engage in a common law suit against all claimants of the Levee in order to settle the question once and for all. No action was taken on the suggestion. 22

The reasoning in the starr case severely undermined the supreme court decision. The city government, as well, was in collusion with Levee claimants in refusing to enforce the injunction against construction on the Levee until after the starr building had been built, which put it in the category of those permanent structures which could then be removed only through petition to the court. This decision did nothing to clarify an already complex situation.

In December 1854, the Portland Milling Company, at the foot of Jefferson Street, burned. The loss of the finished lumber hurt the city's growth in construction, but the rebuilding of the mill was not an easy matter. The site it occupied was on the Levee.

Levi Estes, apparently a law-abiding citizen, sought from the common council a lease to the property which had been formerly occupied by the burned mill. For the Council to make such a lease would have indicated that the city held rights to the property above those of the private claimants. The council of 1854 was not eager to strengthen the public's 
claim and it sought legal advice on the subject.

The city attorney gave an opinion, marvelous in its meaninglessness, regarding the right of the city to lease land on the Levee. He said,

It seems to me that the City may dispose of the property she may have in the Levee in any manner they may think proper with the consent of the owner of fee or claimant of the right to same. Save and except such property as the public necessities require. 23

The city could lease the property, if the proprietors would agree to it. The district court of washington county subsequently decreed that the city had the right to lease Levee land, but such a right was not exercised by the council of 1854-55.

A new common council was elected in April 1855. George Vaughn, Front street proprietor and Levee claimant, became mayor. In May, Levi Estes repeated his petition for lease of the southern block of the Levee; a special comittee was appointed by the new council to investigate the situation.

This special committee later condoned giving a lease to Estes, but the standing committee on Landing and wharves recommended against it. No action was taken. On June 16 , Estes once again petitioned the council for a lease, "providing such a lease would not compromise any legal rights of any parties claiming to be owners of the same." 24 Such a clause, in the light of heated court appeals, gave the council an easy escape. Mr. Estes' petition was denied. 
The Washington County District Court decision that - empowered the city to make leases of Levee property had been reached in the case of Abrams and others vs. Parrish and others. The decision also defined Levee claimants as belonging to two distinct groups (1) those who purchased land without knowing that front street extended to the river; this group held property rights, but owners of lots west of Front held older rights and were not responsible for this group's ignorance and (2) those who had been persuaded to purchase land on the Levee during the first law suit in 1850 and had contracted, among themselves, that certain portions of the Levee were to remain private property. The court decision stated, "The people themselves cannot, even by their unanimous voice, at least without legislative authority, perform a governmental act. - we are a republic not a democracy." This second class of plaintiff was responsible for knowing that the vacation of a highway was a governmental responsibility and that the land they occupied remained a part of Front street.

The judge went on to lambast the common council's duplicitous action in adopting and retaining the Brady map, which had been created at the same time the law suits had commenced, and which the supreme court had labelled "spurious." He also attacked the city council, saying the charter enabled it to, "improve, construct, plank, pave, clear and repair streets, but not to vacate or discontinue 
them." Be also held it had no right to remove court injunctions and authorize the erection of buildings. 25

The judge went on to say that the original plat of Portland had created a

conveyance to the purchasers of these lots [east-facing lots on the west side of Front street] of the right to an open view and way to the river as any form of deed that could be devised. . . and constitutes their principal value.

If the public right to front street, open to the river, were abandoned then private rights would revert to those front lot holders as "their right of access."

The plaintiffs argued that the people regarded the riverfront as private land and had forsaken use of it as a highway. The court argued this by pointing out that the public did not use it as a highway because there were buildings on it, not vice versa. The judge eloguently ended his decision with the argument that, "Adverse possession or omission to use does not prejudice the right of the public nor is any right destroyed by ignorance, or disbelief of its existence." 26 But such ignorance, disbelief and omission of use greatly tempt those who may gain by it to take advantage of it.

The council did little to hinder private activity on the east side of Front Street. In November, Mayor Vaughn ran an advertisement for his business on Front street in local newspapers: "Joseph Lane is elected and George W. Vaughn is still on Front street." The private interests 
were holding fast. For the remainder of that council's tenure water cisterns, sidewalks, fire engines and a fire house were the major topics of business.

In May, a new council granted a lease of property between Morrison and Taylor for the construction of a wharf. The lease was for five years at five dollars a year. On the 24 th day of that month, however, the new mayor, James O'Neill, sent a communication to the council announcing that the old Portland Milling Company site was having buildings erected upon it. Levi Estes, as good pioneers were wont to do, was taking matters into his own hands. Another special committee was formed to investigate the situation.

On May 31, 1856 Levi Estes once again petitioned the common council for a lease to the mill site. After a debate, a lease for ten years at twenty dollars a year was finally granted.

At their next meeting, J.L. Parrish appeared before the council to protest the erection of buildings on Front Street. City Attorney William McEwan also appeared, reiterating the court decisions enjoining construction on the Levee, "Until the decree. - shall, by some higher tribunal than the supreme court of the Territory, be reversed."

At that same meeting, the council engaged McEwan to draw up a lease with Estes, and, in self-contradiction of a most confusing kind, passed an ordinance entitled, "An 
ordinance providing for the removal of obstructions from the Levee." No person was to block the Levee between Washington and Taylor except for wharf-building and shipment of goods, and no obstruction was to remain any longer than three days. The council, by this action, willfully reduced its area of concern to a four block area, reduced from the eight granted in the 1850 compromise. 27

A reflection of waning public interest in the entire matter comes from an editorial in the Weekly eregonian of September 13, 1856. Editor Dryer wrote,

How is it that we have no revenue from the wharves? If the town owns the wharf, why does it not so improve it that it will accomodate the steamers? -.. We would not say a word in prejudice of the private wharves. - . We are aware that this subject is embarrassed by the lawsuit now pending between the city and parties owning portions of the river bank. But the entrance of each street at the waterline belongs to the public. A commencement could be made by grading the bank, and extending the streets to deep water, forming at each a safe and permanent landing place.

Consigning only the ends of streets to public ownership, the city's major whig newspaper supported private riverfront lots. But it was a question: why didn't the council do anything to improve the property the courts had awarded them and the charter empowered them to improve? Not a single council document of the time records any resolution or ordinance to build a public wharf or to make improvements on Front street without specially taxing property holders on both sides of the street.

Another example of how unconcerned the council was 
with the Levee question occurred in the fall of 1856 . The case of Parrish vs. Lownsdale had been appealed to the United States Supreme Court. Josiah Parrish was incapable of supporting the expense of such an action and he petitioned the common council for economic aid for that purpose. But no action was taken until the next year, when an entirely different council was in office.

In April 1857, a new council and mayor were elected and, for the first time, personal property on the Portland waterfront was physically threatened. William F. Burch and B.F. Smith had constructed a tenantable building on the Levee between stark and Oak streets. Though it was not in the traditionally disputed south section of the Levee, the council passed two resolutions enabling the mayor to institute legal proceedings for the removal of the "obstruction" and to petition the circuit court for immediate removal of the building.

On June 3 , the council passed an ordinance providing for the removal of the Smith-Burch building. In council, an attempt had been made to soften the ordinance by changing the length of time the obstruction could remain in place, before forcible removal, from ten days to 99 days, but the amendment failed. Also, on that day, a petition was presented to the council bearing 95 signatures of Portland residents praying for the removal of buildings on the Public Levee and continued prevention of "further usurpation of the 
so called Levee of the City." George Vaughn, former mayor; D.W. Burnside; H.L. Pittock, owner of the reekly Oregenian newspaper: and future governor, Sylvester Pennoyer, were among the more prominent signers of the petition. 28

The council passed an ordinance authorizing the city marshall to notify Sinth and Burch that their building had to be removed within ten days of notice. The mayor returned the ordinance because it made no provision for disposing of the building if the owners demurred from tearing it down themselves. Along with the mayor's veto was a note from Judge olney, authorizing the city to remove the obstruction in question.

On June 23, after securing a suitable lot to which the "obstruction" could be removed, the council authorized sam Holcomb, city marshall, to do his duty. On June 24, the building was removed at an expense of $\$ 161$, and sold on July 6 for $\$ 475$, with the difference going to Smith and Burch. 29

The source of this sudden upsurge of civic feeling for the Levee or, more likely, against Smith and Burch is unclear. The incident nonetheless illustrates the effect the council could have had if there had been strong and constant support for the Public Levee.

The fall of 1857 saw another example of the fluctuating attitude of the citizenry towards defense of the Levee. On August 4, Mayor O'Neill introduced the first proposal to create a Portland townsite claim since such a 
move had been declared appropriate by the Federal Land office three years earlier. However, the resolution was tabled until fall, when a special election was to be held on that and another issue.

J.L. Parrish had received no satisfaction from the previous council to his petition for financial aid for the defense of his suit before the United States Supreme Court. He made another petition to the new council in October 1857. The council decided to hold a special election, at which they proposed a special tax of the citizens, the proceeds of which would go to aid Parrish's defense of the Public Levee. The election also had a second measure on the ballot, whether or not to file a townsite claim.

The results of the election that fall were the adoption of a resolution instructing the corporate officers to file a townsite claim and the special tax measure was defeated "by a substantial majority."30 It is possible the citizens felt that a townsite claim would settle the difficulties of land ownership and support their public rights without the need of taxation. Once again, Portland wanted to go first class on a steerage ticket.

Mayor O'Neill, a supporter of the Public Levee, had resigned before the election, as had commissioner Hallock, also a supporter of the public's land rights. Perhaps they considered the election a ruse. Two new councilmen were elected by the remaining council members to fill the 
vacancies; William King and William McEwan, both strong private property advocates, took seats on the council.

On December 29, 1857 the council chambers erupted as the council attempted to agree on the filing of a townsite claim. Councilman Hardenburgh, a public property man, becoming irate at the handling of the business, charged his colleagues with "chicanery" and labelled them with colorful epithets. The council censured Hardenburgh. The chastised councilman turned the air blue with invective. Hardenburgh was dismissed from his post as councilman. ${ }^{31}$ It became obvious, when the townsite claim was granted the city in 1860, why Hardenburgh had become so upset. The city's claim was designed to give the proprietors' claims paramount importance.

Yet another blow was to be dealt the public claim to the waterfront. Though Parrish could not afford, and the city was unwilling, to employ counsel for the supreme court hearing of the Levee case, the suit was already on the docket, waiting to be heard.

The supreme court did not consider the suit within its jurisdiction because the original suit, having been filed July 29, 1850, was prior to the September 27, 1850 enactment of the Donation Land Law, which was held to be the only legally binding transfer of property rights from the United States to private parties in the oregon Territory. Therefore, no federal laws pertained to the suit. However, 
in the defense of their denial to decide the case, the court recorded its thoughts on it: Lovejoy and Pettygrove had platted Portland at a time when the land was in dispute between Great Britain and the United States, therefore, they had no personal rights to the land. Also, the treaty settling that dispute in 1846 had stated that enactments, "otherwise affecting and encumbering the titles to lands, shall be and are hereby declared to be null and void." 32

Since the federal government had made no provision for individuals to hold land in the oregon Territory until the September 1850 Donation Law, the parties involved in the suit, at the time it was brought in July of that year, could suffer no injury, because neither had any legal rights to the claim at the time.

If they [the people of Portland] have entered such title [to the Levee] it must have been subsequent to september 1850. . . But on the contrary, the pleadings and proofs of the defendants on record show fully that neither Lownsdale, Chapman nor Coffin ever made any such decision. $33^{\circ}$

The Supreme Court of the United States upheld Lownsdale, but because the court ruled the case was outside its jurisdiction, the opinion was not binding, and oregon courts did not readily adopt it. The city council, however, acted as if in full agreement.

1857 was the first year in which the city government had aggressively sought to restrain encroachment on the waterfront. With the steady erosion of Public Levee supporters from the council and the failure of the special 
defense tax, however, the status of public rights deteriorated. In 1858 the U.S. Supreme Court struck a resounding blow against the Public Levee. The townsite claim was submitted that year but left undecided until the bitter fights over private rights were settled.

Though a new city council was elected in April 1858, it took no action in regard to the Levee until January 7 , 1859 when it issued a warning to George w. Vaughn, the former mayor, who was beginning the construction of new buildings on the east side of Front street. No other action was taken at the time, however. On March 25, 1859, the council received a bill from Thomas Carter, a former councilman, for $\$ 100$ to cover the value of lumber removed from the Levee by the city; the bill was ignored. However, on that same day, the city attorney was engaged to draw up an ordinance securing the Levee to the city, and preventing persons from exersizing ownership over it.

On May 25, 1859, the council passed an "Act relating to the townsite of the City of Portland," in which,

No lots, blocks or parcels of land in said City of Portland which have been or are used or reserved or set apart for any public or charitable use shall be subject to private entry and no claim to such lots or blocks or parcels of land by any private person shall be allowed.

This act was to go into effect at the time the city received its patent from the United States Land office. ${ }^{34}$

The act was an attempt to protect the public interest. However, the city had never received the title to public 
lands which was requested when the Brady map was adopted in 1852. D.H. Lownsdale was still waiting for clarification of title. It is also interesting to note that a lot, considered to be land for a public school, and a block, considered to be the site of a public market, were both sold by Lownsdale to private investors in 1859-60. Both of these transactions were to result in new litigation for the city. In effect, the council, by its petition to the General Land office for a townsite claim was trying to protect land which was understood, but never officially dedicated, to be public property.

In the early summer, Mayor McCormick sought an injunction against A.M. and L.M. Starr, who were once again erecting a building on the Levee. Judge Wait awarded an injunction, but further proceedings required a substantial bond, which no citizen was willing to provide. The mayor expressed his frustration by advocating the ejection of all occupants from all buildings along the waterfront, letting them sue the city if they desired to return to those premises ". . the onus of proof in the case would be thrown upon them. " 35

They were not evicted. Instead, in July, Chief Justice white of the circuit court of Multnomah County handed down a new ruling in the matter of the Levee. He declared,

First, that the decision of the oregon supreme 
Court made all the Levee a public highway, and if as such, any part of it was encumbered or obstructed it was to be cleared like any other street, and not by petition, as was attempted in this case [the second case against the Starrs]

and second, Judge White

decided that the decision of the supreme Court of Washington, last winter, entirely annulled the decree of the supreme court of Oregon, and therefore, there [was] no decision upon the Levee question which [had] any force. 36

Such a decision was little help to anyone. Dryer of the Weekly eregenian wrote,

There is now a clear and open field for any jumpers or claimants who desire to 'pitch in.' In the course of the day we expect to see every rod of the Levee occupied, and we predict a harvest of law suits for our legal friends. It is to be hoped that those who have care of our corporate rights under the City Charter will see to it that the shares of each are fairly apportioned. Those who have jumped market, school and graveyard lots and squares, ought not to be allowed to have any part of the Levee, though we fear that their greediness will be above and beyond the sagacity of our stupid officials. 37

On July 20, there was introduced in the council an ordinance to "secure the protection, peace and good order of the City of Portland and to prevent the continuance of a public nuisance." It was designed to uphold the territorial supreme court decision of 1854 which had ruled that front Street extended to the River. The ordinance was defeated on August 3 .

On August 20, the Weekly eregonian carried an article entitled, "City of Portland, jumping, or more properly speaking, attempting to steal the public property of those who have made Portland what it is." The Article did not 
mention the Levee, but was concerned with the transfer of five other city blocks, long considered to be public property, from D.H. Lownsdale to the entrepreneurial partnership of Leland and stout. Portland, already the dominant city in the Northwest, with strong New England ties, had at this time, far less public ground than any East Coast village with its traditional commons.

The only action to occur during the winter of 1859-60, in regard to the Levee, was the appropriation of $\$ 89.50$ worth of wood belonging to D.H. Lownsdale, which had been left on the Levee for more than three days and then removed by the city. What the marshall did with it is unknown, but the council refused to pay Lownsdale's bill.

In February 1860, a petition to prevent private construction on the Levee at the foot of Morrison street was presented to the council. This petition was signed by 16 people, many fewer than the 95 who had signed a similar petition before the destruction of the Smith-Burch building three years earlier. In March, a special meeting of the council was called to deal with the problem. At the meeting an ordinance was presented which broadened the existing powers for the removal of obstructions from the Levee. The rules calling for three readings of a bill before passage were suspended, and the ordinance went into effect with the favorable vote of the councilmen.

The next day a resolution was introduced at the 
regular meeting of the council. This called attention to the latest incursion on the Levee and called upon the marshal to enforce the newly-amended ordinance. ${ }^{38}$ Ex-mayor George Vaughn's building on Front Street was torn down.

Vaughn had signed the petition in 1857 supporting the removal of the Smith-Burch building, but in the intervening three years things had changed. The supreme court and Judge White had nullified the earlier decisions in favor of the city's rights to the Levee. Portland was also growing; commerce was being centered to the north where wharves were already constructed. Good businessmen, such as Vaughn, who had investments along the unimproved Public Levee, were eager to develop the waterfront and reap the financial rewards.

A pamphlet entitled, "Facts for the People of Portland, Relating to the Levee Case," was published immediately after the destruction of Vaughn's building. It lambasted the council for exercising rights over property not belonging to the city, using the United states Supreme Court's reasoning as its basis. It also quoted the city charter, which stated the council could pass only laws "not repugnant to the laws of the United States or to the laws of this Territory," and charged the destruction of personal property as being in violation of this provision. Finally, the aggression against Vaughn was labelled "revenge."

At the end of April 1860, in the midst of excitement 
over new gold discoveries in Idaho, the imminent war between the states and the latest round of litigation on the Levee, a new common council was elected. It appeared the new government would uphold the public claim to the waterfront. In July, notice of further trespass on the Levee was received. Mayor G. Collins Robbins sent a message to the council requesting it

to settle this question, maintain the rights of the City, demand acquiescence from law abiding citizens and to perfect the ordinances of the City so as to punish the violators of the rights and dignity of the City. 39

On August 2, warrants were issued for the arrest of workmen erecting a wharf and warehouse between Madison and Main for J.P.O. Lownsdale, the old town proprietor's son. The workmen were arrested and jailed. The younger Lownsdale was no more willing to accept the situation passively than had been his father. The ensuing law suit was to be the decisive one.

In late 1860 , the council was presented with another petition from 18 lot owners from the west side of Front street praying for the removal of structures across from them, structures which they "feared to be permanent." The petition also asked that bonds be raised to accomplish the removal. In November, Mayor Robbins sent notice of construction of a building on the waterfront across from the council chambers and enjoined the councilmen to take action for its removal. The council did not raise bonds nor 
undertake the removal of the new structures from the Levee. The city was already engaged in suits with Lownsdale and Vaughn, as well as over the ownership of the public market block and school lot.

On December 5, 1860 , City Attorney Douthitt requested the city to employ additional counsel in the cases against the city, but the council took no action. In the year-end edition of the Weekly oregonian, T.J. Dryer expressed his attitude toward the situation:

The legal rights of the public are daily becoming more important. The question of ownerships in lands or streets is yet unsettled. Large and valuable tracts claimed as belonging to the public have been and continue to be encroached upon. Still our laggard City government, with a suppineness that cannot be too severly condemned, suffers the city interests to be in insufficient hanas and the future will tell the tale of the past, that her public levee, her school lands, her market squares, her cemetery, will all be frittered away. 40

In January 1861, the harried city attorney resigned. Later that month, the street commissioner informed the council that he needed to file suit against front street property owners to recover expenses incurred for street cleaning, but as there was no city attorney, the council needed to appoint one. On January 17, George Cartter was elected to represent the city in court, but for some reason he was declared unqualified for the position of city attorney.

On February 3, the council gave Mayor Robbins the power and duty to appoint a special prosecutor to represent 
the city in its four land ownership suits. On February 12, the mayor formally presented George Cartter to the council as special attorney for the city. He also recommended the payment of $\$ 250$ to Mr. Cartter for his services. Along with presenting the new special attorney, the mayor asked the council to fill the regular seat of city attorney as soon as possible.

George Cartter's contract for payment was not acted upon, and there was no provision made by the council for his regular salary until March 20, 1861. On that day, George Cartter was elected city attorney. An ordinance providing for the election of a regular city attorney, which had been struggling through the council since Douthitt had resigned, was defeated. The council had elevated the special prosecutor to the attorneyship with no provision for employing additional counsel. Still, the public was under represented in court. To make matters more confusing, Cartter was to be paid under the provisions of the special prosecutor's contract, which called for him to receive $\$ 250$ for seeing the four major cases through court. 41

On March 22, the eregonian said, "The election of Cartter as City Attorney shows popular sentiment is properly represented in the City Council." But the failure of the city to maintain two attorneys and the months of delay and confusion in filling the posts can be more readily interpreted as malign neglect. In addition, the council had 
made its decisions regarding Cartter just one week before the annual turn-over of city officials. The election of 1861 was to be a bitter one revolving around the city's claims to property.

The eregonian of April 1, 1861, reported the nomination of candidates. The nominating meeting was called on the evening of March 31, at the courthouse. A split occurred in the meeting between those advocating city property rights and those advocating private property rights. A large group of men adjourned to the council chambers where they resolved to protect the public's interest in the guestioned properties. They elected a slate of men sworn to uphold that intent. The group which remained in the court-house put "just enough City men. . on [their] ticket to deceive, and the power was retained in the hands of the friends of private claimants, to turn the Council as they pleased." The eregenian supported the public protectors, listing all of the candidates by marking "City men" with asterisks in order to inform the public of their best choices.

On April 2, the election results were published. John Beck, a "City man" was elected mayor, but the office was only and advisory one, and the mayor would be virtually powerless against an opposition council. The council itself was made up of McCracken, Hallock and Higgins, from the public rights ticket. On the private rights side were 
White, Harbaugh, Hull, Scott and King, an obvious majority. There was one tie, from the second ward, between Masters and Gibbs, both "City men," but the private rights members made Masters their choice and elected him to the council. The privateers were in control

On April 11, committee assignments were made and special offices filled. Private rights men controlled the committee of landings and wharves and, even though Cartter had been elected city attorney barely two weeks earlier, the new council moved for a new election for that office. George Cartter was nominated, as was J.H. Mitchell, Oregon's future senator who later became known for his corruptions and as a target for political reformers during the progressive era at the turn of the century.

It was not until April 30, after two tie votes, that Mitchell was elected over Cartter. Mitchell immediately set to resolving the property ownership battles by forming a committee of reconciliation; in other words, the new city attorney went to work to arrange out of court settlements.

Mitchell did nothing to prosecute Front street property owners for their failure to respond to liens placed on their property for street improvements. On May 24, 1861, the council passed a resolution directing assessment of property on the east side of Front street for taxation purposes. Once again, the city's stance had shifted. The public's hold on the waterfront was further weakened. 
Meanwhile, the townsite patent filed two years earlier had been issued by the General Land office and a copy entered into the book of city ordinances. The patent granted the City of Portland a claim of 307.49 acres, subject, however, to

the decision of the Commissioner of the General Land office. - . expressly reserving any valid claim which may exist in virtue of several Donations of Benjamin Stark, Daniel H. Lownsdale, William W. Chapman, and Stephen Coffin. 42

At the very time the city patent was announced, stephen Coffin was running advertisements declaring his receipt of a patent of 223 acres of land in Portland and guaranteeing deeds to those who had purchased property within his claim. All of this was reassuring to individual property owners, but the city had gained nothing.

Undoubtedly, the city's patent application was designed to favor the donation land claimants. It is no wonder Councilman Hardenburg had lost his temper with his colleagues back in 1858 .

The council continued to erode what claims they might have retained to the Levee. On May 31,1861 , Councilman William King, a leader in the battle against the public's claims, offered an ordinance repealing the ordinance which had enabled the city to remove obstructions from the Levee. He argued that the ordinance to be repealed was designed to get the city into "unnecessary litigation," and "at the same time there are other ways by which the City can assert her 
rights." He did not elaborate those "other ways." The repeal was passed on June 7 , the mayor vetoed the bill, but the council passed it over his objections.

That summer, the suit of J.P.O. Lownsdale vs. the City of Portland was heard before Matthew Deady, but no decision was reached, and the case's final hearing wasn't until December. The summer also saw permanent steps in the resolution of the long battle over the waterfront. Mitchell had formed his "committee of consultation" and was expediting solutions to the city's legal battles. By June 19, George Vaughn was rebuilding on the waterfront.

Early in August, the council passed an ordinance, the first section of which read:

That the owners of private property lying on the western bank of the Willamette River, between Washington and Salmon Streets, and east of Front Street, in the City of Portland, be and are hereby permitted and allowed to build, erect and construct, any and all such buildings, warehouses, docks, wharves, or other improvements on said property as they may deem expedient or think proper and which may be necessary for the accomodation of ocean steamers and the purposes of trade and commerce.43

At the same time Front street was also fully surveyed to place the lots and blocks on its east side accurately. Some buildings had to be moved back from the street line.

Perhaps most telling of all in regard to the motivations of some Portland politicians, and early evidence of John H. Mitchell's peculiar talent for pecuniary politics, was the voting of $\$ 1,000$ annual income for Mitchell, who had abandoned the city's law suits in favor of 
"consultation." On the other hand, George Cartter was never paid the $\$ 250$ he had been voted. Cartter's salary was contingent upon his seeing the four major land cases through court. Since he had been voted out of office and the cases settled without him, his contract was held to be void.

On December 5, 1861, Judge Deady handed down his decision in the case of J.P.O. Lownsdale vs. the City of Portland. the decision echoed the United States Supreme Court of 1858. It annulled all property rights prior to September 1850. Judge Deady also declared what had become obvious to everyone, that the Townsite Law of 1844, enabling towns to claim land, did not extend to Oregon; thus Portland had taken nothing in its entry and patent. Once and for all, he also threw out, as not binding, the compromise Josiah Parrish had refused in 1850, since Parrish had not dropped the suit, as the compromise had required him to do. Deady also held that the compromise was the only recorded intention D.H. Lownsdale ever made public regarding the dedication of the waterfront to public use; other evidence expounding such an intention was held to be hearsay, while concrete evidence supported the opposing view that Lownsdale considered the property his private land.

Finally, Deady stated "If a dedication after the Donation Law exists, it will bind the estate [of D.H. Lownsdale], if it was made before the Donation Law, another decision would have to be rendered." No such dedications 
were ever found. The city had lost. The decision became the final one in relation to the ownership of Portland's waterfront between Jefferson and Washington Streets. 44

One of the final acts of the city council of 1861-62 was the passage of a resolution finally opening the entire riverfront to development.

Whereas there has been controversy as to the ownership of the property east of Front street which has retarded valuable and permanent improvements theron, and been greatly detrimental to the commercial interests of this City and whereas portions of said waterfront have been occupied for years by the houses and wharfing of individuals and private claimants who are ready to make valuable wharves and improvements on other portions of said Front as soon as controversy is ended. . It has recently been decided by the United States Circuit Court for Oregon that the City is not the owner of certain parts of said Front upon grounds equally applicable to all of said property, and whereas further contention about the matter would be only an expense and injury to the City. Therefore, be it resolved by the Common Council of the City of Portland that the City will and hereby does abandon any claim of property. . between Front street and the Willamette River within the corporate limits... the City Attorney is hereby instructed to withdraw and discontinue all notice and proceedings on behalf of the City as to the decree in said District Court ... but this is in no way to affect the right of the city to the streets leading to the willamette River.45

Fortunately, the street ends were saved by a sentence. 
CHAPTER II

INTRODUCTION

The second section of this paper deals with another series of conflicts fought over another portion of Portland's southwest waterfront. Both the earlier and this later series of conflicts involved the failure of the city to improve its commercially valuable public land and its struggle to maintain title to the land in the face of private usurpation of the property. This next round of struggles, though over a smaller piece of property than the battles of 1850-62, brought in a larger array of forces. The later Levee controversies involved the development of rail transportation as well as the rise of grassroots demands for the reform of both government and private corporations. 
COFFIN'S PUBLIC LEVEE AND THE RAILROADS

After the final abandonment of the city's claims to the waterfront in 1862 , private development was rapid. The blocks east of front street were filled with private establishments and became a center of freight and passenger transportation. All of the street ends were leased by the city to entrepreneurs and became built up with private facilities. During the earliest heavy development of the original Levee, Stephen Coffin specifically deeded his waterfront property between Jefferson and Clay streets to the city of Portland for use as a public landing, free to all. It was a good idea and a noble gesture, but the forces of private ownership, lack of city improvements, development of the railroads and intrastate rivalry combined to throw the public waterfront into another maelstrom of litigation.

By 1868, Coffin was disappointed with the city's failure to improve the blocks he had deeded it in January, 1865. He proceeded to transfer title to the Levee to the Oregon Central Railroad Company, on the condition that the company construct a terminal on it within six months. ${ }^{1}$ The deed Coffin executed with the railroad explicitly stated that he had conveyed the property to the city in the expectation of its improvement as a public landing, which would enhance the value of his other holdings in the city. With no such improvement by the city, he felt it his right to transfer the title under conditions which would ac- 
complish his original goal. ${ }^{2}$

The city, rather than litigate the ownership of the Levee, entered into a fee simple contract with the railroad on March 1, 1869, by which date the railroad had failed to fulfill it contracted obligation to construct a depot within six months of its agreement with Coffin. By the terms of the contract with the city the railroad abandoned its claim and swore to defend the city's title to the Levee. Coffin, however, was not satisfied, and when it became apparent no depot would be constructed on the Levee, he contracted use of the property with C.M. Carter. The city once again rescued its claim by entering into another fee simple deed with Coffin and Carter on July 26, 1871, under which the city paid $\$ 2,500$, primarily for a ferry franchise Coffin had continued to hold. The agreement stated that "the City of Portland should have and hold the land. . Iree from all reservations. " 3

But the city continued to let the land lie fallow. Various individuals would occasionally attempt to live on the property, but they were quickly evicted. A noisome group of shanty houseboats was allowed to collect along the bank, a neighboring lumber yard used portions of the land free of charge, and, occasionally, loads of cord wood were temporarily stored on it while awaiting transfer to steamers docked farther north. It was a valuable, though neglected, piece of land. 
New and serious pressures on the city's ownership of the Public Levee began in mid-1880. In April of that year, William Reid, representing Scottish business interests, organized and incorporated the Oregonian Railway Company, Limited. The corporation was formed to construct a network of narrow gauge railroads through the willamette valley and to connect them to the shipping center of Portland in order to provide efficient transportation of goods from the valley to market. It would also offer competition to the monopoly of the Oregon and California Railroad and the Oregon steam Navigation Company, the valley's two main tranport systems, both of which were controlled by the legendary railroad baron, Henry Villard.

The Oregonian Railway needed a good railhead at its terminus in Portland to provide efficient transshipment of goods from land to water. A depot, warehouses and wharfage were required in close proximity to one another. The most obvious and available place for them was the Public Levee.

On June 6,1880 , the Oregonian Railway presented a petition to the common council of Portland asking for a lease to the Public Levee. The petiton was referred to committee. At that same meeting, a previous petition for the Levee's use by Joseph E. Smith, the owner of the lumber yard which was already making use of the Levee, was recommended to be passed on the basis of a ten year lease at fifty dollars a month. 
Action on Smith's petition was held over to the next meeting, where it was indefinitely postponed. The railroad's petition was tabled, and an ordinance "authorizing a lease of the Public Levee to the highest bidder" was also tabled.

The city charter had been amended since the 1860's to provide for three year terms for common councilmen and for rotating elections so that not all of the councilmen would be replaced at the same time. This was done to provide greater governmental continuity than in the earlier pioneer days when one year terms resulted in the total turnover of representatives at each election. Nonetheless, chaos remained the rule in respect to the Public Levee.

In late June 1880, an ailing Stephen Coffin published his own views on the latest scandal involving his gift to the city, stating that if the land were to be sold or leased he considered his right to it paramount; he offered to return the $\$ 2,500$ he had received in 1871 plus interest. At the end of his statement Coffin said, "I never speculated off the City of Portland and I am decidedly opposed to the City converting my donation to the public into a speculation." 4

At about the same time, the city arrested a handful of railroad workmen for trespassing on the Levee. The railway instigated its first suit against the city for possession of the land. 
William Reid, president of the narrow gauge line, wrote a letter to the city attorney, Julius C. Moreland, in which he offered himself for arrest in place of the workmen and, in addition, outlined the motivations of his company. Upon the council's rejection of the railroad's petition for the Levee earlier in June, the company believed section 27 of the General Code of Oregon on Corporations went into effect. The code was quoted in Reid's letter:

Whenever a private corporation is authorized to approppriate any public grounds, if the same be within the limits of any town whether incorporated or not, such corporation shall locate their road on such grounds as the local authorities shall designate, but if such local authorities shall fail or refuse to make such designation within a reasonable time, when requested, such corporation may make such appropriaton without reference thereto.

Reid ended his letter by accusing the city of wanting more rail connections to the rest of the state, but forcing investors to

institute legal proceedings to fight their way into the city of Portland. - . in the face of a law which clearly authorizes this company to locate our depots, tracks, etc. on the public grounds of the City. 5

Attorney Moreland was outraged that he had read Reid's letter in the newspaper before receiving the original and accused the author of ulterior motives in attempting to influence public opinion. He characterized the railroad's precipitous seizure of the Levee as being an attempt to obtain wharfage for the company's ships, as it was "well known that there is not the remotest chance of the company 
bringing a railroad to Portland for years." Moreland also argued there was no "frivolous" opposition to bringing the railroad to Portland by anyone, but there was opposition to the attempted appropriation of property worth $\$ 30,000$ without compensation and to use the land for a purpose for which it was not dedicated. He defended section 27 of the corporate codes as applying to road beds and stated that Reid had not sought a route through the city from the council, but had asked for particular terminus grounds, leaving the council no room for discretion. Moreland argued that the railroad could afford to buy terminus grounds and that "no railway, however limited," could appropriate the Levee before court trial settled the question. 6

Reid made his reply by stating that the road had been surveyed, contracts let and construction was imminent. He also advanced, for the first time, the argument that a railraod terminus was an appropriate use of the Levee according to coffin's deed and that the land had been "reluctantly appropriated as oregon law permitted." 7

On July 2, Judge Charles Bellinger of the criminal court in Portland, passed down the decision that the railroad workers, arrested on the Levee, were not guilty of criminal trespass. He stated in his decision, "If the corporation believes it has the right of appropriation under a statute and so proceeds, its employed agents are not guilty." The judge then referred the question of land 
rights to the civil court. 8

That same day the common council met with Mayor D.P. Thompson, who presented his recommendation to sell the Levee to the highest bidder, with a suggested valuation of $\$ 50,000$, or lease the land on condition of wharf design approval that would include a section of the wharf reserved for public use. The mayor ended his message with a plea to protect the public property. The suggestion was referred to committee.

On the evening of July 6, 1880, Mayor Thompson and City Attorney Moreland met with Reid and the railroad's attorney who were convinced that the city did not own the Levee. Apparently, the railroad had originally considered purchase of the land, but upon investigation of the title it was their interpretation that the city could not grant a deed, that the land belonged to the public and was therefore open to confiscation under the corporate code. Submission of the original ordinance requesting the use of the Levee, had been only a method of clearing minor legal technicalities, a formality to comply with the code before confiscation could proceed. The city representatives denied every argument of the railroad men; attorney Moreland insisted that all work on the Levee cease pending court decision or further trespass proceedings would occur. After an hour, the men parted with no problems solved. ${ }^{9}$

The next day, there was a regular meeting of the 
common council at which a proposed new ordinance entitled, "An Ordinance Disposing of the Public Levee," and an accompanying communication were received from William Reid. The council referred them to committee. Mayor Thompson also gave his report on the previous evening's meeting with the railroad men, informing the council of the railroad's intention to confiscate the Levee without compensation to the city. The temper of the council was evident in their last action of the day; they took from the table a previous ordinance introduced by the mayor which empowered the city attorney to hire additional counsel in the pending Levee suit. This passed unanimously. The council was outraged at the effrontery of appropriation of public property without compensation.

It is too alarming, far-reaching and dangerous to be tolerated until every legal defense shall be made. If this property can thus be taken, public property has no protection whatever.

was the council's statement which reflected its resolve. ${ }^{10}$

On the afternoon of the same day, in disregard of the mayor's and the city attorney's request, the Oregonian Railway Company sent a crew of workmen onto the Levee to continue grading. At 2:00 p.m. the superintendent of streets, William Braden, filed trespass complaints with the police. A warrant was issued, and Detective Hudson and two police officers proceeded up Front street to the Levee, where they arrested seven men and took them back to the city jail. 
The next day, three city attorneys opposed three railroad attorneys before Judge Raleigh Stott of the State Circuit court to argue the validity of City ordinance 321 , passed in 1866 , protecting the public squares from trespass or injury. The railroad held the city had no right to pass such an ordinance; the city was outraged at the supposition that it could not protect public property. That same day, the railroad sent another crew of men to work on the Levee. warrants for their arrest were issued and officers were dispatched, but no sooner were the laborers behind bars than the railroad sent another crew to work, and the police department dispatched new warrants and officers to the scene of the crime. The city was treated, that day, to a strange parade on Front street as the action was repeated until 39 men were in jail. ${ }^{1.1}$

On the ninth of July, ten more men were arrested before Judge stott made his ruling, which held that as the ordinance in question referred only to public property; it was special legislation and, therefore, void as being in opposition to the state constitution, which forbade the legislative assembly from "passing special or local laws... for the punishment of crimes and misdemeanors." Attorney Moreland argued that he could not see how that section of the constitution affected the ordinance. But Judge stott held that, "as the ordinance mentioned and applied only to public property of the city of Portland, it was special 
legislation and therefore null and void under the constitutional provision." The railroad workmen were released.

The decision was much commented on, both by the members of the bar and the public generally, and the almost universal opinion was that the decision. . was far too narrow and contracted and that it could not be sustained.

The city began planning its appeal to the supreme court. 12

On saturday, the tenth of July, the city attorney argued on demurrer before Judge stott that the railroad had not set forth adequate proof to indicate that the Levee should be condemned or that the title should go to the Oregonian Railway Company. The railway attorneys confessed the city's argument was well taken and requested leave to file an amended complaint; stott granted the request. At the same time the mayor threatened to put a fence around the Levee if the railroad didn't stop trespassing. All of this persuaded the Oregonian Railway officials to make no further incursions on city territory until court actions were completed. The Oregenian newspaper applauded the city officers and urged calm while the city waited to hear whether the railway's claim was ". . well founded in law as it certainly [was] not in justice." 13

But the battle over the Public Levee was not only an issue between the railroad officials and the city of Portland. The business and farming interests of the willamette valley desperately wanted the completion of the 
narrow gauge railroad. They wanted lower rates of shipment than they were getting from the other, monopoly controlled, valley transportation lines, and saw the competition of the Oregonian Railway as the best way to secure these lower rates. The city's position against the railroad was not popular in most of the rural parts of the state.

The farmers of the valley were angry. They had constantly sought cheaper methods of shipment for their produce, but felt that Portland had never been sympathetic to their plight. The city had given up even its street ends on the waterfront to private wharves, so that, if the farmers managed to get their goods to the city by cooperative efforts, there was no place in Portland that would charge them fair rates for transshipment. Coffin's Public Levee had been acquired by the city for practically nothing, left unimproved and useless for 15 years and, in the farmers view, had been dedicated as much to the people of the entire state as to the people of Portland. Yet the city refused to let the railroad improve the land and use it for the benefit of the general public. The farmers were angered at the city's demand of $\$ 50,000$ for property it had received for $\$ 2,500$ and totally ignored for years. They were also upset by the meanness of the city, which stood to gain the most from being the terminus of a new railroad. It was widely held, in the hinterlands, that the city was being aided by wide-gauge railroad monopoly interests in 
fighting the popular narrow-gauge. Indeed, Joseph Dolph, who was also Henry Villard's lawyer, was engaged by the city in arguing its case. ${ }^{14}$

The controversy simmered through August but boiled over again in september, when a petition representing two thousand citizens and businesses of Portland was presented to the common council. The petitioners requested the city permit the railroad to use the Levee, fearing that drawn-out litigation would do the city no financial good and would damage its already jaded reputation in other parts of the state. Harvey scott of the eregonian attacked the idea that the city should give up the Levee but supported the railroad terminus. "Like other conveniences in this world, the more the better," he wrote. "Portland wants railroads, but it wants its public Levees and plazas and parks and streets, and it cannot afford to give them away to rich corporations." Scott held that the city owned the Levee as a man owns his home and that if the land is desired by someone else the fair market value should be determined and paid. He did not feel that the small donation of the Public Levee was inducement enough to persuade the railroad to expend the millions of dollars necessary to bring the road to completion. 15 To scott and many other defenders of the city, it was not the property but the principle that fired their crusade.

On the other hand, there were the willamette valley 
interests, whose case was argued by Joseph Gaston, pioneer railroad man and historian. Gaston had built the Dayton, Sheridan and Grand Ronde narrow gauge line, which was one of the major links of the Oregonian Railway system. He argued that the Levee had been dedicated to the public at large by Stephen Coffin, an argument supported by Coffin himself. Gaston stated that as early as 1869 maps had shown the Levee clearly labelled as "Public," while the plazas and parks were not marked. In years past, the city had improved its unmarked properties, but left the Levee unimproved and open to all comers.

"More than ten years have elapsed," he said

and the public has secured a vested right to the land even under the statute of limitations if not by that map and ordinance solemnly declaring and dedicating the land to be for the common and public use. - If the City ever had any private or pecuniary interest in the levee it was all given to the people of Oregon in general. . so that the City does not now own the Levee as the citizen owns his home.

In every act involving the property, it was labelled the Public rather than the City Levee and therefore ". - the city has no more right to grant it away than it has to sell a section of front street, unless the legislature has so authorized in the general incorporation law, "which it had not.

Gaston went on to state that the city would never need the Levee for wharfage, as it was already inadequate for such use. It later became evident, but not until the battle 
was over, that the Levee wasn't adequate for the railroad either. He also argued that the city had already vacated several streets to other railroads and street ends to private wharf enterprises. In addition, the council had leased its market square to the new Mechanic's Fair Association for a nominal fee of $\$ 100$ per annum and the consideration of keeping half of the block as a park. However, the council had

recently assigned, by ordinance, the remaining half of the block to the association with no further considerations, therefore, the park had been wiped out and covered with shacks by an organization run by rich capitalists and which pays higher dividends than any railroad in oregon.

Gaston questioned whether the treatment the railroad was receiving from the city was equitable. 16

On september 22,1880 , a bill was introduced in the State Legislature entitled, "A Bill for an act to grant the Oregonian Railway Company, limited, right of way and station grounds over the state grounds in the City of Portland." Harvey Scott described the bill as giving the railroad "the City of Portland for depot purposes,"17 and said, "as the road is not likely to touch the state land anywhere, the privilege can be one of no great value." 18

The bill also included the granting of right-of-way for a horse-drawn tramway down the length of Front street with turnouts on all street ends in order to accomodate transshipment of produce. The valley interests were solidly lined up to pass the bill against the recalcitrant Portland 
forces.

On October 21,1880 , the state legislature passed the Levee bill over Governor William Thayer's veto, in which he stated,

I can but regard such an attempt as a rude invasion of municipal authority, one worthy of the unfortunate age of aggression upon the rights of local government in which we live. . This attempt to grant it [the Levee] to a railway company is virtually an attempt by legislative fiat to take the property of one party and give it to another, which is a power that has never been delegated to any legislative body. 19

The day before the bill was passed over the veto, a resolution was brought up in the city council, the purpose of which was to congratulate the Multnomah county delegation to the legislature for their steadfast defense of the city's rights. The resolution lost in a tie vote.

During the period of legislative action on the Levee question, the city had received a favorable decision in its land ownership battle in the state circuit court. This the railroad appealed to the state supreme court. It was not until April 18, 1881 that the supreme court upheld the lower court decision that a railroad could not appropriate land dedicated to public use without the city council's approval, nor could it obstruct public access to the property by the construction of permanent structures without the consent of the municipal authorities. 20

The city was delighted with these decisions, but William Reid and his associates paid little attention to 
them. The previous February, the city had appealed the legality of the legislative act granting the Levee to the railroad to the state circuit court and received an injunction against the railroad construction on the Levee. Reid took this injunction to the United States Circuit Court before Judge Deady, who reversed it. Deady allowed for the operation of a track and side-track on the Levee, under bond, until a final decision in the dispute by the United States supreme court. 21

No final decision was ever rendered in that case; developments led to the dropping of the suit. The strength of Scottish capital, which provided the backing for the Oregonian Railway enterprise, had been steadily declining since the failure of the City of Glasgow Bank in $1878 .^{22}$ In the summer of 1881, Henry Villard's associates approached Reid and the other backers of the narrow gauge with a proposal to lease the railway to the oregon Railway and Navigation Company. The O.R. \& N. already dominated willamette Valley transportation. Reid opposed the deal, warning of the destructive motives of the monopoly, against which the narrow gauge battle had been predicated, but the Scottish backers ordered the lease to be entered into, and on August 1, 1881, the Oregonian Railway Company, limited, came under the power of the O.R. \& N.

Reid had been right in his suspicions; the narrow gauge was allowed to deteriorate to the point that its 
system of 143 miles of track became little more than local connecting spurs through the Willamette Valley. The Levee grant called for a terminus to be built there within one year, but the O.R. \& N. never began construction and the grant was annulled. Eventually, the stock and bond holders of the Oregonian Railway were forced to sue the Oregon Rail and Navigation Company for breach of contract; the suit dragged on until 1889 and ended in defeat for the valley interests.

After the fevered debates, the public bickering between city and rural interests, the intervention of the state legislature and the threat of years of litigation, the property between Jefferson and Clay on the riverfront reverted to being a vacant lot. It was used, once again, as lumber yard and wood storage lot, and the waterfront remained a moorage for the houseboats of those who "make night hideous and mar the peace and quiet of the place by their drunken orgies." 23

In early 1884, the city council authorized its first improvements of the Levee, which consisted of driving three rows of pilings out from the bank and inviting ships to dump their balast into the pilings, as well as making the area the recepticle for the street cleaner's debris. Though the city expended $\$ 4,000$ on the extension of the Levee, it was never completed.

On January 19, 1885, the Portland and Willamette 
Valley Railway Company was incorporated with William Reid as president. The new railroad's sole purpose was to complete the link of 28 miles between Portland the old terminus of the Oregonian Railway Company at Dundee, Oregon.

On January 21,1885 , the eregonian newspaper published a letter written to the common council on behalf of the new railroad. The letter outlined the intentions of the $P$. \& W.V. and requested the council to petition the state to award the Levee to the new company in return for "valuable considerations," inculding the free transport of municipal messengers, convicts and lunatics, accompanied by officers, on their way to state institutions and, in time of war, troops and munitions belonging to the state. The privileges were to expire after a period of fifteen years. The letter stated the railway's recognition that the land in question was state property, and that the city had no right to lease it, but that city support would be helpful in attaining a grant from the legislature. Also, as the city had recently given the Northern Pacific Terminal Company thirteen acres in northwest Portland for that company's exclusive use, the petitioners were sure that two acres in the south of the city were not too much to ask for.

Once again, the pot boiled. The next issue of the newspaper attacked the letter as "intended to create. . erroneous inferrences," and stated that "misrepresentations were characteristic of the steal." These remarks centered 
on the connection between the land granted in northwest Portland to the Northern Pacilic Company and the request for the Public Levee in southwest Portland. The Northern Pacific Company had, in the paper's opinion, been give a swamp through which no streets were laid, "on conditions which would secure the filling up of a noisome lake and best serve the owners of the surrounding property." whereas, the new railway was after a "parcel of valuable land having a fine elevation on the riverfront and given to the city for an express public use which he [Reid] wants to convert to a private one." 24

The editorial concluded by accusing "the gentleman from Dundee" of attempting to become a third party in the squabbles between the O.R. \& N. and the old Oregonian Railway. No matter, it went on, how the lawsuits between the two companies ended, the winner would eventually have to finish the Portland-Dundee link, and if Reid controlled that road his power would increase. 25

The common council, later that week, denied the petition from the Portland and Willamette Railway requesting its support, on the grounds that the petition was signed by only one person, Reid. the council requested further knowledge of the railroad's backers. The Oregonian called for an investigation of the company's financing and questioned its timing of the attempt on public property. Why had the company waited until the two other interested 
railroads had fallen out with one another? The way had been clear since 1882, when the legislative grant to the Levee had been forfeited by failure of the narrow gauge to comply with its demands. Once again, the accusation of speculation emerged.

The eregenian reiterated its support of the railroad, but said that the "burglarious and larcenous" part of the plan must be given up. It described Reid as "one who is so shameless in his methods of 'business' that even his own countrymen are compelled to testify he is not to be believed in any statement he makes." 26

In its January 31 st edition, the newspaper attacked Reid's

pretense of conferring a benefit on the whole people of the Willamette valley [as] sheerest impudence. Better say that he lost money on mortgages and dodged taxes for years, not for his benefit, but for theirs.

At 4:00 p.m., February 9, 1885, the state legislative assembly erupted. In an earlier meeting of the railways and transportation committee, a bill granting the Levee in Portland to the Portland and Willamette Valley Railway had been introduced and voted on with Representatives L.B. Cox and H.S. Davenport against it and Representatives W.L. Prosser, M.J. Connor and Henry Cyrus supporting it. The opposition made clear to the other members of the committee its intention to present a minority report. Later that afternoon, Cox was called to the chair of the house by the 
Speaker. A few moments later, Prosser took the floor and read the Levee bill with committee recommendation to pass it. Cox was taken completely by surprise; the minority report was not yet prepared, and Prosser had presented the bill in such a way as to make it sound as if it had full committee support. Cox, being in the chair, was unable to protest.

Upon being relieved of the chair, Cox, who was from Umatilla county, took the floor, and "with some display of passion," drew the house's attention to Prosser's reading. Charging his coleague with taking unfair advantage of his (Cox's) position in the chair to present an incorrect report, Cox also charged prosser with designed and direct falsehood. Davenport, Cox's co-opponent to the bill, seconded the statements. Legislator Prosser rose to the defense, stating that, as the house was reading bills the third time, his committeemen should have known he would make a reading. A motion was made to table the report until the next day, but it was 10st. Cox and Prosser then proceeded to vent their anger at one another, and a point of order was raised and sustained.

A motion was made to recommit the bill at a later date to allow for the minority report. This motion, too, was lost. Prosser's reading of the bill was adopted by the house, as the committee report, at which time, both Cox and Davenport requested to be excused from further service on 
the transportation committee; their wishes were granted by the speaker. 27

The next day, the bill was presented to the senate where opponents attacked the secrecy of the Portland and Willamette Valley Railway organization and its backing asserting that the bill was intended to enrich speculators. Lawyers and lobbyists for the railroad spoke, but could name no stockholders. A Senator Bilyeu rose and argued that the articles of the company's incorporation were filed in the secretary of state's office, open to the public, where the question of officers could be easily answered. He ended his speech by support of the bill; in regard to its speculative nature, he stated that he "didn't care how much the railroads cinched each other." 28 such a cavalier attitude did not help his constituents with their non-competitive freight rates.

The entire day was taken up by the Levee debate and the nature of the new corporation's purpose. The identity of its investors was never fully revealed to the senate. Joseph Simon of Portland attempted to amend the bill, with an assessment of $\$ 70,000$ to be paid the city by the railway, but the amendment was defeated. He presented a second amendment calling for the compensation due the city to be determined in court before the railroad could take possession. The second amendment passed and was hailed in Portland as a virtual defeat of the railroad's intentions, 
as most city defenders remembered the state supreme court's decision in 1881 retaining rightful title to the property for the city.

On February 13, the final Levee bill passed as amended and became law. The Multnomah county delegation voted solidly against it, but made no statements, which disappointed many of their constituents because of what appeared to be their compliant submission to its passage. Harvey Scott was indignant. Even if the land were the state's to grant, he reasoned, why would the state be any less reluctant than the city to give it away for nothing? He decried its loss along with that of school, swamp and tidelands to "grabbers, speculators and monopolists." 29

In November of 1885, the Portland and willamette Valley Railway offered bonds to the state of Oregon covering the construction costs of the new railroad. The action brought out the names of W.S. Ladd, Van deLashmutt, Aaron Meier and other prominent Portlanders and Oregonians as backers of the enterprise. The bonds were approved.

In that same month, the heirs of Stephen Coffin, who had died in March 1882, filed suit in the United States Circuit court against the city and the railway, charging breach of trust. The Coffin heirs also argued that the city held the Levee as a public trust, that it had been illegal for the city to tax private wharves and property owners for the construction of free wharves and that therefore, a 
Public Levee was "unkown to law, science or history," and that the original dedication was void. They also alleged that the act of 1885 granting the property to a private corporation was a renunciation of the original deed and the property, therefore, should revert to the heirs of the original owner. 30

Judge Deady of the circuit court held that land once donated to the public could not revert to the original owners, even if not improved, and that its occupation by private parties did not constitute a loss of public title to the property. He also refuted the supposition that there was no such thing as a Public Levee by tracing the concept's origin in the southern and midwestern United States. Most importantly, he labelled the act of February 1885, granting the Levee to the railroad, as a "mass of senseless and redundant verbiage." He ruled that neither the state nor the city could dispose of the property nor dedicate it to a purpose inconsistent with the original dedication. He decided that, if the property were to be used adversely to its dedicated purpose, injured parties could obtain a court injunction against the perpetrators of the misuses. Nonetheless, the property could not revert to the private ownership of the heirs. 31

Less than two weeks after their defeat, the Coffins filed a second suit alleging that the city had had no right to accept the original deeds from their father in 1865 and 
1871. In the new suit they argued that those deeds were void due to the city's representing itself falsely in the second deed and to its failure to execute the purposes intended by the donor.

In the spring of 1886 , the state circuit court for Multnomah county had decided that the city, as trustee for the public, had no pecuniary interest in the property, and therefore the railroad was not required to pay compensation. Even so, the Portland and Willamette Valley Railway offered the city $\$ 7,600$ for the loss of improvements on the Levee. The company was offering the sum as inducement for prompt council action; the railroad hoped for completion of the road by the end of october 1886. The council stalled all action regarding the Levee through the spring and fall by referring all proposals to the judiciary committee and the city attorney. 32

The city had appealed the state circuit court decision to the state supreme court. On November 29,1886 , the supreme court passed down its decision, in which it stated that the Levee grant could be construed to be beyond the legislature's power, but that it was the court's duty to interpret the law and make it valid rather than to annul it. The court upheld Deady's proposition of state stewardship of the Levee, but went beyond him to define the city of Portland as a corporation, existing at the sufferance of the state. 
The decision held that the streets and public grounds of the city were public to all the people of the state and not just to those of the city; therefore the state held control of those grounds, but the state did not have the power to dispose of them. It upheld the railroad's argument that its use of the land was not inconsistent with the Levee dedication as a public landing with the added benefit of a railway connection. The supreme court held the railroad to be the state's custodian of the Levee. It was also decided that the state's decision to change its designated trustee of the Levee from the city to the railroad entitled the city to receive compensation for its investment in the property, and remanded the assessment of damages to the state circuit court. 33

In late November, 1886 , the case was heard before the state circuit court again, the city arguing that the act of 1885 was void on two counts; the legislature had dedicated the Levee to a purpose inconsistent with the intentions of the original donation, and the act had made no provision for compensation. The court upheld the demurrer on the second count and dismissed the case. The railroad then appealed the case to the supreme court, which reversed the lower court and again remanded the case for determination of compensation due the city.

J.G. Chapman, son of one of Portland's original proprietors and lawyer for the Coffin heirs in the suits to 
regain the Levee, wrote a letter, published in the December 11 edition of the oregonian. He quoted several cases of similar disputes in which the Supreme Court of the United States had interpreted the use of public levees, streets and squares by railroads as repugnant to the public interests and the acts of state legislatures granting such properties to railroads as void.

Chapman also quoted the Levee act of 1885 , in which the Levee was "to be under the exclusive management and control of the owners of the railroad," and he lambasted the state supreme court's decision interpreting that language as merely designating the railway as an agent of the state. He argued that the railroad, as a private corporation, would exclude the public from the Levee except when transacting private, railroad business.

Chapman cited the case of Todd vs. The Railway Company, a suit heard in ohio, in which it was decided,

If the premises are to be maintained for charges, gain and profit, it becomes no more than any other private wharf or warehouse and is not a public use for which property can be dedicated.

The very idea that the railroad could be construed as an agent of the state in upholding the original purpose of the dedication flabbergasted Chapman. As the act had created no new state agency and the court had no power to revise legislation, he held the act void in the full meaning of its terms. Chapman understandably ended his letter with the call to return the property to the heirs. 
On the same day the letter was published, a group of prominent businessmen, including and ailing William S. Ladd, left the dock at the foot of Jefferson street and travelled to Elk Rock, five miles south of Portland, the point to which the Portland and willamette Valley Railway had been completed. Although the railroad was heavily embroiled in court suits, not only with the city and the coffins, but with condemnation proceedings against owners of property over which the road was to be built, the corporate guests enjoyed a gala opening of their railroad.

On January 1, 1887, regular passenger and freight service on the P. \& W.V. opened with ferry service from the foot of Jefferson Street at the American Exchange wharf to Elk Rock, where rail service commenced.

1887 was the watershed year in the battle over Coffin's Levee. It began with the decision of Judge Erasmus Shattuck in favor of the Coffin heirs in opposition to the state supreme court and the United States Circuit Court. Though he did not have the power to reverse the higher court decisions, the heirs gained some legal recognition in their battle and motivation to continue their fight. Court actions were stalled and both the assessment of city compensation and the final decision in the Coffin case were not decided until the end of the year. Meanwhile, the Portland and Willamette Valley Railway was involved in over sixty condemnation suits, and it is possible it used these 
suits to stall action on the Levee question.

In May 1887, rumors were confirmed that the P. \& W.V. had been purchased by the Pacific Improvement Company which controlled the Southern Pacific Railroad. The interest on the narrow gauge bonds was previously being paid by that syndicate. $^{34}$ Pacific Improvement also owned the Oregon Railroad and Navigation Company and the Oregon and California Railroad, which have been mentioned as holding a monopoly on Willamette Valley transportation. Once again, any remaining hopes for competitive rates through the completion of the narrow gauge railroad evaporated. A month later, on June 18, the common council granted the railway a right-of-way over land owned by the municipal water works, below Palatine Hill, without compensation, other than an agreement for the railroad to construct a switchline to the city engine house and to keep it in repair.

In November, the railway, from a temporary depot at the foot of Lincoln street, opened service on its line from Portland to Dundee, doing away with the cumbersome transfer by river between the city and Elk Rock. Already, statistics indicating the quadrupling of property values in south Portland and suburban areas along the rail route created popular excitement and support for the railroad. 35

The opening of the Southern Pacific controlled oregon and California Railroad's newly completed track all the way to California was being arranged at the time. The oregonian 
carried an article encouraging the inclusion of the narrow gauge in the celebrations. The paper said, "Mr. Reid, who was the prime mover in the Oregonian Railway Company as well as the Portland and willamette Valley deserves a big bumper." 36 Even the most stalwart protectors of public property were being seduced by the prospect of economic growth.

On December 9, the Oregonian announced that workmen had begun grading on the Levee and suggested "a cold chill ran down the spinal vertebrae of all the city officials." It is more likely a weary resignation came over them. Three days later, Judge Shattuck, acting on the Supreme Court's directive to determine compensation due the city, made his decision. The city was to receive $\$ 8,751.87$, for the $\$ 2,500$ paid to Coffin in 1871 plus 88 interest per annum from that time, as well as the value of the piling driven during 1884 . On December 2l, the city attorney reported the results of the suit to the council, which in turn instructed him not to file for a new trial in the case. The city had resigned itself.

The final coffin suit was decided in mid-February 1888, by the supreme Court of Oregon. The court held that Stephen Coffin had not, in any of the questioned deeds, reserved rights to the property he had deeded to the city. On the contrary, the second deed appeared to the court as confirmation of his intentions to dedicate the Levee to the 
public without reservation. Therefore, the heirs were considered to have no title to the land, even though the city had never used the property for its dedicated purpose. The court confirmed Judge Deady's view of the railroad as the state's agent. Sitting on the bench at the time was W.W. Thayer, who, as governor in 1881, had vetoed the first legislative grant of the Levee to the Oregonian Railway and decried the assault on the city's property rights. 37

On March 12, 1888, the city auditor recorded the receipt of $\$ 8,672.87$ for the Levee property. Some court costs had been deducted from the award. On July 24, 1888, the first $P$. \& W.V. train left the new and permanent depot at the foot of Jefferson Street amid the cheers of a large crowd.

It had been a bitter battle and the pressures of development had won over supporters of public property. The city never passed an ordinance or resolution giving up its interest in the property; those interests had been determined by the courts and the city had been compensated. There was no further need for council action.

In one respect it was a good thing the city lost its suits against the railroads, for if it had managed to sell the Levee for $\$ 50,000$, title to the property would have resided permanently with the railroad. As the case stood, the title remained with the state, and the railroad merely occupied the land without owning it. This set of new 
circumstances provided the ingredients for an entirely new round of contention between the public interests and the railroads thirty years later.

The earliest movement, in 1880 , to possess the Public Levee, free of charge and to establish a competitive railway, was a fairly good example of the grass roots reform movement occurring in the United States at the time. The farmers and local interests of the rural regions of the state enthusiastically supported the prospects of cheaper shipping rates and resented the monopolistic control by city capitalists of transportation facilities. The Levee became a symbol. The Levee was public property dedicated to cheap, even free, shipping of goods into and out of Portland, but when this popular use for it was suggested, the city refused to let it be so used. Of course, the rural areas interpreted this as the act of capitalists protecting their monopolies. There is certainly evidence to support this view. Eventually, this grassroots movement to reform and open up the corporately controlled transportation and shipping systems was crushed by the powerful monopolies.

In 1885, some of the same popular sentiment was apparent, even so, the second attempt was a much more corporately influenced undertaking. Twice in the 1880's the Willamette Valley had been enticed with the possibilities of lowering transportation costs to the port at Portland through the construction of narrow gauge railways that would 
compete with the more established lines. Twice those hopes were destroyed. These events and the rough-handed appropriation of the Levee for private uses by a business monopoly are examples of the type of actions forced upon the public by corporations and government alike during the late nineteenth century. The public's frustration at these actions culminated in the widespread demand for reform during the progressive period of the early twentieth century • 


\section{CHAPTER III}

\section{INTRODUCTION}

Chapter three of this paper deals with the twentieth century. The period has seen the total metamorphosis of the waterfront, from a run-down commercial center to a broad, open field, awaiting the execution of publicly approved plans which will make it a cosmopolitan playground. The waterfront in this century has experienced the effects of every major economic development of the time, including urban renewal, depression era public works, supermarket and freeway construction and environmental protection. The waterfront continued to be embroiled in important law suits, demanding much of the city's attention. The purpose of this section, however, is not so much to reveal the motivations behind these later law suits as simply to provide a sketch of recent history and to illustrate the steps the area went through on its journey to becoming, finally, public property. 
COFFIN'S LEVEE IN THE TWENTIETH CENTURY

The dawn of the twentieth century saw a changing waterfront. The central business district of Portland had moved west, to Sixth Avenue, far enough from the waterfront to avoid both the constant flooding of the untamed Willamette and the roughness of Front street, which was filled with delivery wagons and the Southern Pacific's trains running down its center. The shanty-like docks on the old levee had outlived their usefulness. Predominately, river boats used the old docks; larger vessels were docking farther north where more land was available for construction of more efficient wharves and bigger warehouses and where rail lines were heavily concentrated at Union Station and Albina. The Front street wharves were crowded, unimproved and capable of handling only small-scale, local shipping transactions. There was widespread concern in the city over them as threats to health, as fire traps and as aesthetic insults.

In 1909, the voters approved a bond issue to raise $\$ 500,000$ for public docks. The mayor, Joseph Simon, an Oregon Railway and Navigation Company lawyer, in cooperation with the common council, refused to sell the bonds, the reasons being that docks and wharfage were better left to private enterprise and that municipal facilities would constitute unfair competition. The populace, disgusted with the activities and near monopoly of the railroads on the 
waterfront of the city, used one of the recently won progressive reforms, the initiative, to amend the city charter and create the Portland Commission of Public Docks. The commission had the power to levy taxes and sell bonds, independent of the city government. One of the objectives was to clean up what had been the Public Levee. ${ }^{1}$

The docks commission was formed in 1910, the same year Oswald West was elected governor of Oregon. West rode the crest of progressive reform into office. A Democrat in a Republican state, he defeated the well-oiled political machinery of the time with his support of popular, anti-corporate ideals. It was through the individual effort of Governor West that stephen Coffin's donation to the public at the foot of Jefferson Street was recaptured from the railroads.

With the assistance of the city attorney of Portland, West had a bill introduced to the 1911 legislative assembly repealing the 1885 Levee grant. The bill failed, but a resolution calling for further investigation and a formal report to be given to the next session passed. The governor called upon A.A. Jayne, a Portland attorney, and senator Claud C. McCullough of Baker to make the investigation and report.

In the 35 years the railroad had held the land, the wharf had fallen into disrepair and disuse, the warehouses were empty and the depot was used only for commuters. There 
had been a shift in those years from the shipment of wheat from the valley to the shipment of finished products, such as flour: it was this excuse the railroad used to explain the decline of business on the site. ${ }^{2}$

However, the land had changed hands in 1892 from the Portland and Willamette Valley Railway to the Portland and Yamhill Railroad Company, another agent of the Southern Pacific monopoly, and in the next year it was sold to the Oregon and California Railroad Company, another corporation under the control of Southern Pacific. The Public Levee as a major shipping point had been obsolete when the railroad opened it as such in 1888. Heavy shipping had shifted north. It had become better business for shipments to arrive nearer the Union Station railyard, which were also controlled by the Southern Pacific syndicate, and to bypass the inadequate, secluded little dock at the foot of Jefferson.

In December 1912, the railroad approached the city with an offer to give the city the dock on the waterfront and a right-of-way to it on its tracks, if the railroad were allowed to keep its depot grounds and if the city were to recognize the railroads rights in the property. By the first week in January 1913, negotiations had broken down, as the city held to the argument that the railroad had broken their agreement with the state by not maintaining an adequate dock and that, therefore, it had forefeited its 
right to the property. ${ }^{3}$

By the time the city and railroad negotiations had failed, the legislature was in session and Governor West had already recommended to it the revocation of the 1885 grant and the reversion of title to the Levee to the city of Portland. Senator McCulloch of Baker recommended reimbursing the railroad for its improvements to the property, at the replacement value of $\$ 50,000$, even though the dock at the time was in "such dilapidated condition that the public is barred off it to prevent possible injuries." 4

Senate Bill 293 was introduced by Dan Kellaher of Multnomah County. The bill provided for the reversion of all rights to the property and its improvements to the state, which would in turn revert to the city upon reimbursement of the state's expenses relating to the compensation to the railroad. By February 26 , the bill had not been acted on by the house, which had referred it to the ways and means committee twice. Once again, West communicated with the legislators, attacking the railroad lobby's attempts to stall the bill and to prevent its coming to a vote at all.

Ironically, there was some confusion among valley and rural representatives as to why the city of Portland was unable to act on its own behalf in the matter. The complicated history of legislative actions and court cases of three decades earlier had to be recited to the represen- 
tatives from areas which had been most responsible for the Levee grant of 1885 in the first place. On February 26 the bill was called out of committee and placed, as a special item, on the very same day's docket of business. The few objections heard were shouted down. By the next day, Multnomah county legislator, Jay Upton, who had worked tirelessly against the bill, saw imminent defeat and left the floor without voting. The bill passed the house with only three dissenting votes. 5

On August 2, 1913, the state of Oregon and the Oregon and California Railroad entered into a quit claim deed for the Public Levee. The state kept its $\$ 50,000$. In return for ten dollars the railroad abandoned all of its rights to the property except those improvements leased to it by the city of Portland through its commission of public docks. 6

The Jefferson street Levee was the first stretch of the downtown waterfront to come back into the control of public agencies. The old railroad buildings were torn down, and a small passenger depot was built back from the river near the intersection of Columbia and Front. The wharf was strengthened, and in 1919 a municipal paving plant was constructed on its south end. The paving plant was the result of public outrage over the exhorbitant prices the city was forced to pay private macadamizing companies for the paving and repair of city streets. Iike the docks commission, the paving plant reflected the voters' 
willingness to defy business protests in order to accomplish needed public works at low cost. The enterprise was so successful that the Jefferson street plant, which produced 200 tons of asphalt a day, was replaced by a 500 ton facility in Albina in 1928. 7

other than for the paving plant, Coffin's Public Levee was used for no public purpose until the late 1930's. By the late $1930^{\prime} \mathrm{s}$, the battleship Oregon had been retired from the United States Navy and presented to the city of Portland as a memorial to the Spanish American War and in order to save it from becoming scrap. A popular drive to provide a permanent home for the war memento was headed by Mrs. C.S. Jackson, wife of the founder of the oregen Journal. The drive attracted contributions from people as diverse as local school children and President Franklin Roosevelt. The federal government granted $\$ 25,000$ to the project, and work excavating a berth for the ship at the foot of Jefferson street was begun in May 1938. The new park was officially dedicated in september of that year.

Since 1925 the Spanish American War Veterans of Oregon had been collecting money for a memorial to Theodore Roosevelt and to their fallen comrades. The monument was originally intended for Battle Rock on the southern oregon Coast, but the battleship monument seemed a more fitting place for it; the statue was completed in early 1939. The park was, unfortunately, short-lived. World War 
II broke out two years after its completion, and the state offered the battleship to the navy. There were some romantics who hoped to see it returned to service, remodelled as an aircraft carrier, but the navy towed the obsolete warrior to Kelso, Washington, where it was scrapped. Near the end of the war, the hull was used to barge war materiel across the Pacific, used as a breakwater on Guam and, ultimately, ignominously scrapped by a modern Japanese enterprise. ${ }^{8}$

The "Rough Rider" statue, standing 18 feet high and weighing 48 tons was dismantled by the city and state to make way for highway construction in 1941. Originally intended for storage in the city's stanton street yards, the statue has since been misplaced. All contacts with city agencies and other efforts to discover it have presented no leads. Had the park been able to survive, it would have been a point of civic pride today, but had the war not destroyed it, the automobile would have.

Harbor Drive had been on the planning boards for many years. The combination of widening front street and building the new highway was expected to relieve westside auto congestion. By 1943,878 of all work necessary for the roadway's completion had been started. By the early 1950's, an elaborate interchange, connecting burgeoning traffic flows, completely obliterated Coffin's Levee and extended out over the old battleship moorage where, in its place, a 
small boat marina had been created in the shadow of massive concrete pilings.

Harbor Drive was closed to traffic in 1974 after it was replaced by the Fremont Bridge and the Stadium Freeway. In the summer of that year, Harbor Drive was torn up, and the Levee, left vacant and unused except for sailing classes and infrequent swimmers who used the marina.

In the summer of 1979 , the state officially authorized the city to use the land for park purposes. Today, it is part of the South Auditorium Improvement District. Work has begun on the construction of an amphitheatre on the old Levee and moving the public marina southward. It is unfortunate that after all the attempts to use coffin's Levee for its dedicated purpose as a free, public landing, it is currently proposed to divert it from that use. But perhaps Stephen Coffin's spirit would be appeased if he were given the credit he is due by having the proposed amphitheatre named for him.

THE PUBLIC LEVEE IN THE TWENTIETH CENTURY

Coffin's Levee has come back to public ownership in this century and is finally being developed for the general public. However, this paper began with the history of the waterfront between Washington and Jefferson streets, and that area, too, has come back to the public.

The citizens of Portland had createc a dock commission 
in 1910, part of the duties of which were to clean up the downtown waterfront. Front Avenue frequently flooded in the spring, and the crowded, wooden structures along the bank were allowed to deteriorate by their owners. As early as 1890 the stretch of shabby wharves and the murky, crowded prospect of Front Avenue warranted no mention in Harvey Scott's Histery of Portland other than as being "wholly utilitarian" and uninviting. The area was regarded by the general populace as dangerous to the city in regard to fire, disease and general unwholesomeness, but the property was controlled by some of Portland's biggest business interests, including the Pittock, Ladd, Corbett and Failing estates, as well as by the railroads, large real estate concerns and Portland Gas and Coke, forerunner of Northwest Natural Gas. Overhead on the docks was low and profits high, even though local river traffic was in decline; there was great resistance on the part of vested interests to interference with their still lucrative business. 10

In 1920, Olaf Laurgaard, city engineer, unveiled a master plan for the downtown waterfront, which the city council accepted; it was adopted as official in 1923. His plan called for the construction of a seawall, an interceptor sewer, a public market and a huge, new railway station at the foot of the city's main downtown streets. A twenty-foot wide promenade for the public was to be squeezed in between the tracks and the river. This narrow lane of 
concrete along the seawall could hardly have been used for more than a walkway for transients, but in the minds of most, any change would have been an improvement. The city proceeded to condemn the buildings east of Front. ${ }^{11}$

Some property owners stalled demolition with court actions. A.L. Barbur, city commissioner of public works, was forced to close several street ends serving wharves owned by recalcitrant merchants who refused to make improvements on the streets leased to them. The improvement plan called for the sale of serial bonds for the purchase of and reconstruction of the waterfront. It was commonly held, however, that the property owners were holding out for top dollar. 12

In March 1921, Commissioner Barbur called a meeting of 200 downtown businessmen and property owners and announced that the passage of a bond issue was doubtful, due to sluggish markets and lack of voter support. He said that property owner cooperation in the new improvements was necessary if the district were to be stabilized and refurbished into a viable business area and the decline in land values reversed. He stated that the city was willing to lease a portion of the property for a public market and that the railroads had already expressed interest in a new depot and willingness to move their tracks. ${ }^{13}$

The group's cooperation was not forthcoming, however, and the plan stalled. The most stubborn of the litigants 
was the Pioneer Real Estate Company, which originally alleged that the destruction of their docks and the resultant inaccessibility of the river would lower their property's value; the company ultimately fought battles over the feasibility of the interceptor sewer, their assessment for improvements and the underestimation of the improvement costs. It was not until 1927 that the final case against the city was lost. The waterfront had, once again, been a no-man's land, battled over by public and private interests.

By 1927, merchants were tired of their basements' flooding, local river traffic had all but disappeared and the downtown district had voted the sale of bonds on their property assessments to cover the expenses of building the seawall and sewer. Construction began in the spring of 1927, and the work was finished in the summer of 1929 at the cost of 2.7 million dollars.

The seawall was phase one of the waterfront improvement plan. Phase two was the construction of a new public market. Since 1914, a thriving congested and colorful street market, operated by the city, occupied the vicinity of Yamhill street east of Fifth Avenue. From the time of Laurgaard's first proposal to move the market to the waterfront, there had been contention over the desirability of the move. Occupants and shoppers alike defended the open market, arguing that not only would the market's asset of being near the retail center of Portland be lost, but that 
its unique atmosphere would be destroyed. City and investment forces, on the other hand, argued the need for parking and against the questionable sanitary conditions of the Yamhill street Market. The district property owners, who were paying heavy improvement assessments on the seawall and sewer with the understanding that the riverfront market would bring business to that area, were heavily in favor of the new market building.

The Portland Public Market Company announced plans for the new public market in June 1927. The Market Company was a private enterprise and issued stocks and bonds to cover purchase of property and construction costs. Original investors included some of the city's leading financial forces. Construction was stalled, however, over financers' questions about the company's indebtedness to the city. These questions arose because the city had vacated street ends to the company at no charge. Financers also balked at organized, popular opposition that was fighting to keep the market center at Fifth and Yamhill. Finally, the collapse of the economy delayed construction. 14

There had been two alternative sites proposed by competing market companies, both presenting sites on Fifth Avenue, near the retail core. But it was the forces of the depression as well as the strong governmental and financial backing of the the Front street site that decided the final location of the new public market. 
There was strong pressure from labor unions for the city to start construction as a work relief project. In addition, the two sites favored for the market by the opponents to the waterfront site were more expensive than the Levee site. Finally, it had become apparent that the city, if it were to have a market at all, would have to subsidize its construction.

In october 1931, the city council formally entered into an agreement with the Public Market Company, under which the city agreed to purchase the structure at the time it was a "going concern" through issuing utilities certificates. The city entered into the contract even though Ralph Clyde, commissioner of public utilities and a vehement opponent of the plan was out of town. ${ }^{15}$ The council also ignored petitions from over 18,000 market customers and farmers requesting that the market remain near the retail center. In November, a citizens group led by Walter Whitbeck presented a petition to the city auditor calling for a referendum on the issue, charging the city was offering a franchise, as well as that the city's financial commitment to the project would raise taxes and therefore should go before the voters. The auditor and the city attorney denied the charges and refused to accept the petition. ${ }^{16}$ whitbeck took the case to court.

In May 1932, Mayor Baker, City Engineer Laurgaard, and two commissioners were indicted for malfeasance and negli- 
gence in office for committing the city to excess payment of $\$ 200,000$ for the Front street site. It was charged that they had accepted an inflated appraised value in their agreement with the market company. The defense lawyer argued lack of evidence and denied the charges. Commissioner Clyde was accused of perpetrating the disgraceful affair. The case was quickly dismissed. ${ }^{17}$

In July of that year, the state supreme court upheld the city auditor's refusal to accept the petition demanding a referendum. In October, the city accepted a $\$ 775,000$ loan from the newly formed federal agency, the Reconstruction Finance Corporation, which, in an effort to relieve unemployment and stimulate the economy, made federal funds available to self-liquidating projects. It was the first R.F.C. loan in Oregon and used most of the funds available to the city, thus precluding other projects. ${ }^{18}$ Construction of the market finally began in the spring of 1933 and, incredibly, was opened in December of the same year.

As predicted, the Yamhill market, street stall merchants boycotted the new market, and it quickly became apparent that abundant parking and an expansive, sanitary, new building were not enough to draw a full house of business. In June 1934, the Portland Public Market Company insisted the city honor its contract and liquidate the company's holdings by selling the utilities certificates. The city had already held that the half-empty market was not 
a "going concern" as was required in the contract signed in 1931. The city also argued breach of contract due to cost overruns by the company during contruction of the mammoth market. The city insisted it was not obligated to take the market over from the company. Once again, the city and private business were back in court over the waterfront ownership, but the situation was reversed; this time, no one wanted the Levee.

From 1934 to 1946 the land use was mired in litigation. In the early 1940 's, Harbor Drive was installed through the market's rear parking lot, and Front street was widened. During World War II, the United States Navy leased the structure, primarily as a warehouse. Otherwise, the vicinity was shunned by the populace as a sterile eyesore. The waterfront became useful mainly as a highway and parking lot.

In 1946 , the state supreme court ruled that the city was not the owner of the market, but was liable for damages to the R.F.C. and the market company for over one million dollars. The United States Supreme Court refused to hear the city's appeal, and the city was forced to pay the reparations in 1947. The city paid huge damages but received no title; ${ }^{19}$ The oregon Journal had purchased the building in 1946, refurbished it as a newspaper plant and ran its presses there until 1961, when the paper was purchased by the oregonian. The new owners then made it a 
storage warehouse.

In 1948, the Portland Visitor's Center was constructed south of the Market building, between Front street and Harbor Drive. It was designed by John Yeon and, unlike most structures the waterfront had seen, was hailed as an architectural show-piece. It was used as a visitor's center until 1965 and was made into city offices in 1967 after it had been saved from demolition by architecturally aware and concerned citizens. Unfortunately, it has undergone several modifications of the original design. 20

The public market, however, had no such distinction. On May 23, 1969, the building was finally purchased by the city, ironically with the aid of funds from the federal government. The intention was to create a park. Businessman Stan Terry filed suit to stop demoliton of the building but not for esthetic reasons. He insisted the city use the old market for the municipal court and holding jail. The suit was thrown out of court, and the market took almost as long to tear down as it had to build. The land became a grassy, vacant strip between Harbor Drive and Front street. Harbor Drive, as has been mentioned in section one of this chapter, was closed in 1974, after completion of the Stadium Freeway, and was torn up that same year. The waterfront has remained virtually unchanged from that date except for the beautification of front street with new street lighting and trees. The area north of the portion 
of the waterfront concerned in this paper has received more attention than has the old Public Levee. A new square, terraced to the river, and a widened promenade with benches and open railing in the seawall to permit a view of the river grace the area between the Burnside and Morrison Bridges. The mast and bow shield of the old battleship oregen form a new, though pale, monument to that favored symbol of patriotism which once was a floating museum on the river. However, the modern use of the area once sold by Daniel Lownsdale to entrepreneurs in violation of the public trust is, still in the planning stages.

After 130 years, much of it spent in litigation and animosity, the people of Portland possess their downtown waterfront and have committed themselves to improving it for its esthetic qualities rather than for its commercial possibilities. The plans call for some business development in the area to help attract people, but it is doubtful that this area will ever again be used for intensive speculation. The role of the waterfront for the city-at-large has, one hopes, shifted from the struggle for money and power to the communal appreciation of beauty and environment. 


\section{CONCLUSION}

It was mentioned in the beginning of this paper that the Oregon Territory was being settled at the same time that large estates in New York state were being broken up in the anti-rent war. Those New York estates were left over from the semi-feudal conditions that were imported to the new world from Europe in the colonial centuries. The breakdown of those estates was due to the influence of democratic ideals after the revolutions in politics, society and economics in the late eighteenth century. Traditional forms of land use were not so readily rejected in the American South. The battles over the Portland Public Levee illustrate the clash of two concepts of land use and the triumph of the individual, commercial influences on the American frontier in the mid-nineteenth century.

The donation of the Portland waterfront to the public by Lovejoy and Pettygrove was a futile act. Portland's financial leaders were predominately New Englanders, and thoroughly pragmatic businessmen. There was, at the time, little sympathy for what were perceived to be antiquated concepts of land use. The economic and social revolutions of the time undermined the power of government in favor of commerce. Nowhere is this more evident than in the loss of the waterfront from the public through weak government and 
persistent private pressure.

The ravaging of American society and government by the power of centralized wealth, which was the outgrowth of the industrial revolution and the unrestrained exploitation of resources, was reflected in the actions of the railroad on the Levee. The maturing of American government and social awareness in the twentieth century also had enormous effect on the waterfront, illustrated in Coffin's Levee being reclaimed as public property. As well, the original Public Levee in the twentieth century illustrates the current tendency of failing private enterprises to expect public assistance for their salvage.

Thus the waterfront reflects, in its struggles and developoment, the dominant economic and political movements of its time. It does, however, also reveal a very basic attitude on the part of Portland's citizenry and government. The desire to "go first class on a steerage ticket" has been held to be, perhaps, the city's most annoying trait.

The waterfront has been an obvious victim of a penchant for economy. The failure to provide funds for defense before the supreme court in 1857, the failure to improve the property, the fiasco of the public market, all represent major failures of city policy due to a reticence to make investment expenditures of tax dollars. The city has opted instead for duplicity, inaction and poor planning. 
At present, the immediate future of the waterfront is, once again, thrown into doubt due to the resurgence of national and local political and economic conservatism. A grassroots desire to break government power in favor of unrestrained commercial activity has gained strong, national influence. Locally, the old line alliance between business and government, so dominant and destructive to good planning in the past, has gained prominence in city hall. Given Portland's southwest waterfront's history of reflecting major economic and political trends in its land use, it seems clear that this narrow strip of currently undeveloped land will, once again, embody a major development in Portland's ideological and urban evolution. 
ENDNOTES

\section{Chapter I}

1 Eugene E. Snyder, Early Portland: Stump-Town Triumphant (Portland: Binford and Mort, 1970), p. 31.

2 snyder, p. 67.

3 Daniel H. Lownsdale Papers, Oregon Historical Society MS. 177.

4 Facts for the People of Portland Relating to the Levee Case (Portland: n.p., 1860), p. 1 .

5 Facts for the People of portland, p. 2.

6 "Papers of the Provisional and Territorial Governments of Oregon," Oregon Historical Society MS. 1226 , item 2743.

7 "Papers of the Provisional and Territorial Governments of Oregon," item 2743.

8 Daniel H. Lownsdale, "Notice," Weekly Oregonian, 3 May 1851, p. 3, col. 3.

9 "Records of the Common Council of the City of Portland, 1851-1867," Oregon Historical Society Microfilm from Oregon State Archives, 6 May 1852.

10 "Records of the Common Council," 6 May 1852.

11 E. Kimbark MacColl, The shaping of a City: Business and Politics in Portland, Oregon, 1885-1915 
(Portland: Georgian Press, 1976), pp. 230-231.

12 "Records of the Common Council," 14 March 1853.

13 J.B. Preston, "Portland Claim," Weekly Oregonian,

2 July 1853, p. 2, col. 5.

14 Oregon Historical Society MS. 177, n. pag.

15 Oregon Historical Society MS. 177, n. pag.

16 "Portland Land Claim," Weekly Oregonian, 5 Nov.

1853, p. 2, col. 2 .

17 "Papers of the Provisional and Territorial Governments," item 4705 .

18 "The City Council," Editorial, Weekly oregonian, 8 Apr. 1854, p. 2, col. 1.

19 Portland Common Council, "Council Documents" (200111), 1859, Portland Archives and Records Center.

20 John Wilson, "Confirmation of the Decision of the Commissioner of the General Land office in Relation to Town Sites under the Donation Law," Weekly Oregonian, 10 June 1854, p. 3, col. 1 .

21 "Land Claims and Town Sites in Oregon," Weekly Oregonian, 2 sept. 1854, p. 2, col. 1 .

22 "Council nocumentș," 1854.

23 "Council Documents," 1854.

24 "Council Documents," 1855.

25 "Portland Levee Case," Weekly Oregonian, 26 May 1855, p. $2, \operatorname{col} .6$.

26 "Portland Levee Case," Weekly Oregonian. 
27 Portland Common Council, "Book of Ordinances, 1854-1868," Oregon Historical Society microfilm from Oregon State Archives, p. 72.

28 "Council Documents," 1857.

29 "Council Documents," 1857.

30 Facts for the People of Portland, p. 6 .

31 "Records of the Common Council," 29 Dec. 1857.

32 Facts for the People of Portland, p. 9.

33 Facts for the People of Portland, p. 9.

34 "Records of the Common Council," 25 May 1859.

35 "Council Documents," 1859.

36 "Circuit Court - City Property," Weekly oregonian, 16 July 1859, p. 2, col. 2 .

37 "Circuit Court - City Property," Weekly Oregonian.

38 "Records of the Common Council," 21 March 1860.

39 "Council Documents," 1360.

40 "Our City Government," Oregonian, 29 Dec. 1860, p. 1, col. 3 .

41 "Records of the Common Council," 20 March 1861.

42 "Ordinances," p. 158.

43 "Council Documents," 1861.

44 "City - United States' District Court - Deady Justice," Oregonian, 15 June 1861, p. 3, col. 1.

45 "Records of the Common Council," 28 March 1862. 
1 "The Levee Title," Editorial, Oregonian, 12 oct. 1880, p. 3, col. 3 .

2 stephen Coffin, "The City Levee," Oregonian, 12 oct. $1880, \mathrm{p} .3, \operatorname{col} .3$.

3 Coffin, "The City Levee," Oregonian.

4 Stephen Coffin, "General Coffin Rises to Explain the Public Levee Question," Oregonian, 30 June 1880, p. 1, col. 6.

5 William Reid, Letter, Oregonian, 30 June 1880, p. I, 6 Julius C. Moreland, Letter, Oregonian, I July 1880 , p. 3, col. 3 .

7 William Reid, Letter, Oregonian, $3 \mathrm{July} 1880$, p. 3, col. 1 .

8 C.B. Bellinger, "The City Levee Question," Oregonian, 2 July 1880, p. 3, col. 4 .

9 "The Levee Question," Oregonian, 7 July 1880, p. 5, col. 5 .

\section{${ }^{10}$ Richard Gerdes, "Common Council," Oregonian, 8 July} 1880, p. 3, col. 3 .

11 "More of the Levee Question," Oregonian, 9 July 1880, p. 3, col. 3.

12 "The Levee Question," Oregonian, $10 \mathrm{July} 1880, \mathrm{p}$. $3, \operatorname{col} .2$. 
13 "The Levee Suit," Oregonian, 12 July 1880, p. 3, col. 4 .

14 R.C. Greer, Letter, Oregonian, 17 July 1880, p. I, col. 6 .

15 "The Levee Question," Editorial, Oregonian, 2 sept. 1880, p. 3, col. 4 .

16 Joseph Gaston, Letter, Oregonian, 6 Sept. 1880, p. 3, col. 4 .

17 "A Study in Figures," Editorial, Oregonian, 23 Sept. 1880, p. 2, col. 1 .

18 "The Railway Job," Editorial, Oregonian, 1 oct. 1880, p. 2, col. 1 .

19 W.W. Thayer, "Veto of the Levee Bill," Oregonian, p. 1, col. 5 .

20 "The Public Levee," Oregonian, 19 Apr. 1881, p. 3, col. 4.

21 "The Public Levee Again," Editorial, Oregonian, 20 Apr. 1881, p. 2, col. 1.

22 E. Kimbark MacColl, The Shaping of a City:

Business and Politics in Portland, Oregon, 1885-1915 (Portland: Georgian Press, 1976), p. 69.

23 "The Public Levee," Oregonian, 23 Jan. 1884, p. 3, col. 3 .

24 "The Levee Steal Again," Oregonian, 21 Jan. 1885, p. 2, col. 2 . 25 "City," Oregonian, 22 Jan. 18?5, p. 2, col. 3. 
26 "The one Plain Objection," Editorial, Oregonian, 30 Jan. 1885, p. 2, col. 1.

27 "The Levee Bill Leads to an Angry Dispute," Oregonian, $10 \mathrm{Feb} .1885$, p. 2, col. 3.

28 "The Senate Discusses the Portland Levee Bill at Length," Oregonian, 12 Feb. 1885, p. 4, col. 3.

29 "Set-Back for the Levee-Snatcher," Editorial, Oregonian, $13 \mathrm{Feb} .1885$, p. 2, col. 1.

30 "The Courts," Oregonian, 10 Nov. 1385, p. 3, col. 5.

31 "the Portland Levee," Oregonian, 13 May 1886, p. 3, col. 1 .

32 George P. Bissell, "The Levee Again," Oregonian, 1 May 1886, p. 2, col. 3.

33 Matthew P. Deady, Reports of Cases Heard in the Circuit and District Courts of the United States of oregon and California 1859-1869 (San Francisco: Bancroft, 1872), XIV, p. 188 .

34 "Railway Matters," Oregonian, 10 May 1887, p. 8, $\operatorname{col} .3$.

35 Portland City Council, "Minutes of the Proceedings of the City Council," (2001-03), 1887, Portland Archives and Records Center, p. 309.

36 "mhrough to Portland," Oregonian, 27 Nov. 1887, p. 2, col. 1 .

37 Deady, Reports of Cases, XVI, p. 77. 


\section{Chapter III}

1 E. Kimbark MacColl, The Shaping of a City:

Business and Politics in Portland, Oregon, 1885-1915

(Portland: Georgian Press, 1765), pp. 385-6.

2 "Southern Pacific Levee Problem is now Deadlocked," Oregon Journal, $6 \mathrm{Jan} .1913, \mathrm{p} .3, \mathrm{col} .1$.

3 "Southern Pacific Levee Problem," Oregon Journal.

4 "Levee Investment of S.P. Co. Shown as Being

$\$ 62,947, "$ Oregon Journal, $13 \mathrm{Jan} .1913, \mathrm{p} .3, \mathrm{col} .1$.

5 "House Responds Overwhelmingly to West's Demand that Jefferson Levee be Pestored," Oregon Journal, 27 Feb. 1913, p. $1, \operatorname{col} .2$.

6 Multnomah County, Assessment and Taxation,

"Records," Book 634, p. 30 .

7 Portland Public ?orks, Annual Report, (8400), 1928, Portland Archives and Records Center, p. 7.

8 Dick Fagan, "Mill Ends. ..." Oregonian, 2 Nov.

1941, sec. 1, p. 17, col. 1 .

9 "Teddy Statue off to storage," Oregonian, 2 Nov.

1941, sec. 1, p. 15, col. 3.

10 "keen Interest is Arroused in Plans for New

Harbor," Oregon Journal, $8 \mathrm{Feb}$. 1920, sec. 3, p. 1, col. 1.

11 "More speed in Demolishing is Asked by Barbur,"

Oregon Journal, 16 Nov. 1920, p. 2, col. 1.

12 "Rule Condemning Water Frontage Property Eought," 
Oregon Journal, 18 Nov. 1920, p. 3, col. 7.

13 "Property Owners Join to Develop Water Frontage," Oregon Journal, 25 March 1921, p. 16, col. 1.

14 E. Kimbark MacColl, The Growth of a City: Power and Politics in Portland, Oregon, 1915-1950 (Portland: The Georgian Press, 1979), p. 490.

15 Maccoll, The Growth of a City, p. 494.

16 "Petition Entered on Public Market," Oregonian,

15 Nov. 1931, p. 19, col. 14.

17 "Market Set-Up Laid to Clyde," Oregonian, 12 May 1932, p. 1, col. 8 .

18 MacColl, The Growth of a City, p. 494.

19 "Final Farewell," Editorial, Oregonian, 24 Dec. 1968, sec. 1, p. 26, col. 1 .

20 "Portland Buildings, Visitors' Center," oregon Historical Society Verticle File. 


\section{A IIST OF WORKS CONSULTED}

\section{Manuscripts}

Lownsdale, D.H. MS. 177. D.H. Lownsdale Papers. Oregon Historical Society, Portland.

\section{Government Documents}

Multnomah County. Assessment and Taxation. "Records." Multnomah County Assessment and Taxation Records, Portland. Jooks 634 and 199.

Multnomah County. Circuit Court. "Reports of Cases Heard." Multnomah County Circuit Court P.ecords, Portland. $1861-62,1881,1885-1887$.

Oregon. Provisional and Territorial Governments. "Papers of the Provisional and Territorial Governments of oregon." MS 1226. Oregon Historical Society, Portland.

Oregon State. Highway Commission. Report. Salem: 19401942 .

Portland. City Council. "Minutes of the Proceedings of the City Council." (2001-03), Archives and Records Center, Portland. 1885-1887, 1913-1934.

Portland. Common Council. "Book of ordinances, 1854-1868." Oregon State Library, State Archives, Salem. 
Microfilm, Oregon Historical Society, Portland. Portland. Common Council. "Council Documents." (2001-11), Archives and Records Center, Portland. 1851-1862, $1871-1887$.

Portland. Common Council. "Records of the Common Council of the City of Portland, 1851-1867." Oregon State Library, State Archives, Salem. Microfilm, Oregon Historical Society, Portland.

Portland. Public Works. Annual Report. (8400), Archives and Records Center, Portland. 1919-1928. Portland. Treasurer. "Peport." (2002-12), Archives and Records Center, Portland. 1888. Washington County. Circuit Court. "Records of Cases Heard." Oregon State Library, State Archives, Salem. Microfilm, Oregon Historical Society, Dortland. $1851-1858$.

Newspapers

Oregon Journal. (1907-1974), Portland. Oregonian. (1860-1862, 1880-1887, 1931-1974), Portland. Portland Telegram. (1920), Portland. Weekly Oregonian. (1851-1860), Portland. Collected Documents, Letters and Works Deady, Matthew P. Reports of Cases Determined in the Circuit and District Courts of the United States of 
Oregon and California: 1859-1869. San Francisco:

A.I. Bancroft, 1872. Vols. XIY and XVI.

"Portland Buildings." Vertical File. Oregon Historical

Society, Portland.

"Portland Waterfront." Vertical File: Oregon Historical Society, Portland.

Monographs and special studies

Corporate History of the Southern Pacific Company and

Proprietary Companies Comprising the Pacific System as of June 30, 1916. San Francisco: Southern Pacific Valuation Department, 1919.

Facts for the People of Portland Pelating to the Levee Case. Portland: n.p., March 1860 .

Merriam, Paul Gillman. Portland, Oregon, 1840-1890: A Social and Economic History. Diss. University of Oregon 1971. Ann Arbor: University Microfilms, 1971.

Scott, Edna A. The Grange Movement in Oregon, 1873-1900. Thes. University of Oregon 1923. Salem: Oregon State System of Higher Education, 1939.

General Works

Gaston, Joseph. Portland: Its History and Builders. Portland: S.J. Clarke, 1911. Vol. I.

Lang, H.O., ed. History of the Willamette Valley. Portland: Himes and Lang, 1885. 
MacColl, E. Kimbark. The Growth of a City: Power and Politics in Portland, Oregon, 1915 to 1950. Portland: The Georgian Press, 1979. The Shaping of a City: Business and Politics in Portland, Oregon, 1885 to 1915. Portland: The Georgian Press, 1976.

O'Donnell, Terence and Thomas Vaughan. Portland: A

Historical Sketch and Guide. Portland: Oregon Historical Society, 1976.

Scott, Harvey. History of the Oregon Country. Cambridge: Piverside Press, 1924. Vol. IV. History of Portland. Syracuse: D. Mason, 1890. Snyder, Fugene E. Early Portland: Stump-Town Triumphant. Portland: Binfords and Mort, 1970. 